\title{
Recent Advances in Biological Systems for Improving Indoor Air Quality
}

Norbertus Joannes Richardus Kraakmanª,c, Javier González-Martínª,b, Cristina Pérez ${ }^{\mathrm{a}}$, Raquel Lebrero $^{\mathrm{a}, \mathrm{b}}$, Raúl Muñoz ${ }^{\mathrm{a}, \mathrm{b}}$.

\footnotetext{
${ }^{a}$ Institute of Sustainable Processes, University of Valladolid, Dr. Mergelina s/n., Valladolid 47011, Spain
}

${ }^{b}$ Department of Chemical Engineering and Environmental Technology, University of Valladolid, Dr. Mergelina s/n., Valladolid 47011, Spain

c Jacobs Engineering, Temple Quay 1, Bristol, BS1 6DG, United Kingdom

Corresponding author: bart.kraakman@jacobs.com

\section{Abstracts}

Studies on human exposure to indoor air pollution reveal that indoor environments could be at least twice as polluted as outdoor environments. Indoor air pollution has not received as much attention than outdoor air pollution, despite an adult spending now most of the time indoors as a result of the global shift in the economy from the manufacturing sector towards the service and knowledge-based sectors, which operate in indoor office environments. Additionally, the health threats caused by a long-term exposure to indoor air pollution have become more apparent over the last decades as buildings are progressively sealed against the outside climate conditions to obtain heating and cooling energy cost savings and in response to stricter safety guidelines. Currently there is not a single technology that can efficiently provide a complete and satisfactory purification of indoor air. Biological systems for improving indoor air quality are promising, but challenges need to be considered to properly address the bioavailability of low pollutant concentrations, guarantee microbial safety, and incorporate $\mathrm{CO}_{2}$-removal. This study presents the recent research advances in biological 
indoor air purification methods as a 'green' alternative to physical-chemical methods, with emphasis on current challenges and opportunities it can provide for improving Indoor Environment Quality, building energy cost savings and improvements on indoor comfort and well-being.

Keywords: Indoor Air Quality, Indoor Environmental Quality, Biofiltration, Membrane Bioreactor, Capillary Bioreactor, Photobioreactor.

\section{INTRODUCTION}

\subsection{The indoor air quality problem}

The indoor concentration of air pollutions is almost always higher than the outdoor concentration of air pollutions because outdoor-sourced contaminated air enters indoor occupied spaces and combines with indoor-sourced pollutants (European Commission, 2003; EPA, 2020). Indoor air pollution has not been acknowledged as outdoor air pollution has been, especially in highly industrialized or dense traffic areas. However, the health threats of indoor air pollutants caused by their long-term exposure have become more apparent over the last decades as buildings are progressively sealed against the outside climate conditions to obtain heating and cooling energy cost savings (EEA 2019) and as a result also of stricter safety guidelines. Modern buildings cultivate higher indoor air pollutant concentrations because they increasingly rely on mechanical ventilation with greatly reduced outdoor air ingress.

At a global level, the World Health Organization (WHO) estimated that each year 3.8 million people die prematurely from illnesses ascribed to indoor air pollution, much of this due to cooking or heating, which represents $7.7 \%$ of the global mortality (WHO 2018). For most European countries the economic cost to society of household air pollution is significant in terms of gross domestic product (WHO 2015), with for example annual expenses of up to 
52 20,000 million $€$ in France (Anses 2014). Moreover, health problems such as respiratory are compounded by sick building syndrome (Burge 2004). Additional to health impacts, poor IAQ has been shown to reduce workplace productivity by 10-15\% (Cincinelli et al. 2016). Between $80 \%$ (developed countries) and 90\% (EU-28) of the average 250 million liters of air a person breathes during their life (about 10,000 liter per day) is sourced from indoor sources (houses, workplaces, schools, shopping centers, public buildings or means of transport (Royal College of Physicians, 2016). Similarly, the USA Human Activity Pattern Survey found that an average adult spends $86 \%$ of their time indoors and an additional $6 \%$ inside vehicles or public transport (Marć et al. 2018). IAQ has been classified as a priority concern for children's health (EU Environmental Agency 2019) and one of the USA's largest environmental threats (Guieysse et al. 2008).

Indoor air pollutants include particulate matter, bioaerosols and over 400 different chemical compounds, mainly volatile organic compounds (VOCs) for instance formaldehyde, BTEX (benzene, toluene, ethylbenzene and xylene) and trichloroethylene, and inorganic compounds (VICs) for instance carbon monoxide (CO), carbon dioxide $\left(\mathrm{CO}_{2}\right)$, nitrogen oxides $\left(\mathrm{NO}_{\mathrm{x}}\right)$ and ozone $\left(\mathrm{O}_{3}\right)$. Pollutant sources and emission rates may rapidly change over time (Luengas et al. 2015). Indoor pollutant sources include permanent sources (building materials, carpets, paints, varnishes, etc.) and occasional sources (furniture, cleaning and disinfection products, cooking, personal care products, tobacco smoke etc.), while outdoor pollutants intrusion mostly depends on human activities (road traffic, industry, etc.) (Hubbard et al. 2005). Table 1 summarizes the most relevant indoor air pollutants, their typical sources and commonly used measurement methods. Recorded indoor air pollutant concentrations and their physical-chemical properties are summarized elsewhere (Gonzalez-Martin et al., 2021). 


$\begin{array}{lcc}\text { Indoor Air } & \text { Typical Pollutant Sources } & \text { Common Measurement } \\ \text { Pollutants } & \text { Methods }^{2}\end{array}$

\begin{tabular}{|c|c|c|}
\hline $\begin{array}{l}\text { Particle Matter } \\
\left(\mathrm{PM}_{2.5} \text { and } \mathrm{PM}_{10}\right)\end{array}$ & $\begin{array}{l}\text { Indoor sources: ovens, heaters or stoves, fireplaces } \\
\text { and tobacco smoke. Outdoor anthropogenic } \\
\text { sources: combustion processes, industry and } \\
\text { traffic. Outdoor natural sources: dust from sand or } \\
\text { sea salt, pollen or fire ash. }\end{array}$ & $\begin{array}{l}\text { Real-time direct reading } \\
\text { instrument; light scattering } \\
\text { airborne particle counter }\end{array}$ \\
\hline Bioaerosols & $\begin{array}{l}\text { Pets, mould, insects, sick occupants, } \\
\text { (de)humidifiers or improper air filters (and may be } \\
\text { attached to Particle Matter). }\end{array}$ & $\begin{array}{l}\text { Impactor (air sampler directed } \\
\text { onto a growth surface intending } \\
\text { microbial colony enumeration) or } \\
\text { metagenomic techniques }\end{array}$ \\
\hline
\end{tabular}

\section{Volatile Organic Compounds (VOCs)}

\begin{tabular}{|c|c|c|}
\hline Formaldehyde & $\begin{array}{l}\text { Resins, glues, paints, paper products, cosmetics, } \\
\text { electronic equipment, cleaning agents and fabrics. } \\
\text { Construction materials such as insulation foams } \\
\text { and wooden-based materials in floorings or } \\
\text { furniture (note that emissions from some of these } \\
\text { materials, e.g. plywood, usually decay within } \\
\text { several weeks after installation). }\end{array}$ & $\begin{array}{l}\text { ISO 16000-3, ASTM D5197, } \\
\text { NIOSH 2016, EPA TO-11 (or 11A) } \\
\text { or EPA Method IP-6 (or 6A). }\end{array}$ \\
\hline BTEX & $\begin{array}{l}\text { Indoor sources: combustion devices, tobacco } \\
\text { smoke, construction materials (polymeric } \\
\text { furnishings, carpets, paints, wooden furniture, } \\
\text { resins, coatings and adhesives), cosmetics, } \\
\text { cleaning products and pharmaceuticals. Outdoor } \\
\text { sources: traffic and industrial activity. }\end{array}$ & \multirow{3}{*}{$\begin{array}{l}\text { Tenax sorbent followed by thermal } \\
\text { desorption and GC-MS or MS-FID } \\
\text { as per ISO 16000-6, ASTM D5197 } \\
\text { or EPA TO-17 } \\
\text { (and includes Total VOC) }\end{array}$} \\
\hline Trichloroethylene & $\begin{array}{l}\text { Lubricants, varnishes, paint removers, adhesives } \\
\text { and typewriter correction fluids and some bleach } \\
\text { household products and other cleaning agents. }\end{array}$ & \\
\hline Terpenes & $\begin{array}{l}\text { Perfumery products, deodorizers and cleaning } \\
\text { products, air fresheners, deodorants, fragrances and } \\
\text { shampoos. Terpenes can also originate from } \\
\text { furniture or flooring made from pine wood. }\end{array}$ & \\
\hline
\end{tabular}

\section{Volatile Inorganic Compounds (VICs)}

\begin{tabular}{lll}
\hline $\begin{array}{l}\text { Carbon } \\
\text { monoxide }(\mathrm{CO})\end{array}$ & $\begin{array}{l}\text { Indoor sources: defective cooking and heating } \\
\text { devices, fireplaces, tobacco smoke and vehicle } \\
\text { gases from attached garages. Outdoor sources: } \\
\text { dense traffic or high industrialized districts. }\end{array}$ & $\begin{array}{c}\text { Real-time direct reading } \\
\text { instruments }\end{array}$ \\
\hline $\begin{array}{l}\text { Nitrogen oxides } \\
\left(\mathrm{NO}_{\mathbf{x}}\right)\end{array}$ & $\begin{array}{l}\text { Indoor sources: gas appliances like stoves, ovens } \\
\text { or heaters. Outdoor sources: power generation, } \\
\text { industries and traffic. }\end{array}$ & \\
\hline Ozone $\left(\mathrm{O}_{3}\right)$ & $\begin{array}{l}\text { Photocopier machines, laser printers and other } \\
\text { electronic devices with high voltage. Outdoor }\end{array}$ & \\
\hline
\end{tabular}




\begin{tabular}{ll}
\hline & $\begin{array}{l}\text { sources: photochemical reactions in the presence of } \\
\text { VOC, } \mathrm{NO}_{\mathrm{x}} \text { and UV light. }\end{array}$ \\
\hline $\begin{array}{l}\text { Carbon dioxide } \\
\left(\mathrm{CO}_{2}\right)\end{array}$ & $\begin{array}{l}\text { Occupants producing } \mathrm{CO}_{2} \text { as well as fireplaces and } \\
\text { some cooking and heating devices. }\end{array}$ \\
\hline & $\begin{array}{l}\text { Radon is a radioactive gas that is released through } \\
\text { the decay of radium in soils and rocks and enters } \\
\text { indoor air spaces of buildings or other enclosed } \\
\text { locations. }\end{array}$
\end{tabular}

${ }^{1}$ (WHO 2015; (Rösch et al. 2014)

2 (International WELL Building Institute, 2019)

\subsection{Prevention and Treatment of Indoor Air Pollution}

Maintaining a healthful indoor environment is increasingly important as buildings are progressively sealed to obtain energy cost savings in building heating, ventilation and air conditioning (HVAC) or due to safety regulations. A comprehensive understanding of indoor air pollutants (type, concentration and variability in space and time) is relevant for the development of effective control strategies both in terms of prevention and active abatement. Prevention should be considered as the first step for improving IAQ and therefore, some measures have recently been implemented to eliminate certain pollutant sources. The European Directive 99/77/EC restricted harmful construction materials (e.g. asbestos) and products containing hazardous components (e.g. halogenated pesticides) and workplace and public places now commonly ban smoking in many countries. Such control at the source is achievable when sources are known, whereas new hazardous substances are recurrently detected. It is therefore technically difficult and economically exorbitant to completely prevent indoor air pollutants at all time (Guieysse et al. 2008; Luengas et al. 2015). Additionally, increasing concern with greenhouse gas emissions has led many countries to commit to zero energy buildings and to enhanced energy performance during major renovations of existing buildings (European Directive 2010/31/EU). New building design standards such as Passivhaus involve well-insulated and sealed construction, which removes or reduces natural ventilation, 
increasing the risk of gas and particulate indoor air pollutants accumulation (Broderick et al. 2017). This conflict between energy efficiency and IAQ standards points to an increased need for development of effective in-situ indoor air purification systems.

Active purification units can be installed to lower or eliminate hazardous levels of indoor air contaminants. Mechanical and electronic filtration as well as adsorption and ozonation comprise most systems commercially available. These physical-chemical technologies have been traditionally installed as portable units or as part of the central heating and ventilation system (Luengas et al. 2015; González-Martín et al. 2021). However, these systems still present multiple drawbacks. For instance, the simplest and most used method for PM removal is mechanical filtration, which is based on circulating air through a fibrous material that retains particulate pollutants. However, frequent filter replacements are required to maintain the capture efficiency and prevent the re-emission of particulate pollutants. On the other hand, electrical filtration attracts and retains negatively charged particles on a plate of opposite polarity. Unfortunately, by-products such as ions, ozone or other compounds may be generated during electronic filtration (Luengas et al. 2015; Hubbard et al. 2005). Adsorption involved the retaining of pollutants on a surface and happens because all molecules employ attractive forces, especially molecules at the exterior of solid materials (e.g. pore walls of activated carbon), and these surface molecules seek to adhere to other molecules. The exact nature of the bonding depends on the details of the species involved and the adsorbent materials such as activated carbon, zeolites, alumina, silica gel and polymers. The adsorption process may be a combination of a physical processes, such as the weak van der Waals forces, or chemical processes, with the characteristic of covalent bonding (Luengas et al. 2015). Regular replacement of adsorbent materials is required to prevent pollutants re-emission and to maintain efficiency levels. Potentially harmful microorganisms can be also accumulated and re-emitted. Finally, electronic ozonization relies on the generation of $\mathrm{O}_{3}$ from ambient $\mathrm{O}_{2}$ by 
high-voltage discharge or UV radiation. However, Luengas et al. (2015) also found that despite

the abatement efficiencies of electric ozonisers are being superior to other physical-chemical methods, VOCs and VICs can react with $\mathrm{O}_{3}$ (a strong oxidant) during ozonisation and form hazardous secondary pollutants. In addition, health issues may arise from potentially toxic indoor levels of $\mathrm{O}_{3}$, which has a typical exposure limit of only $0.1 \mathrm{ppm}_{\mathrm{v}}$ for 8 hours (Luengas et al. 2015; Hubbard et al. 2005; Chen et al. 2005)

This paper presents the recent research findings on biological indoor air purification methods as a 'green' alternative to physical-chemical methods for improving indoor air quality, with emphasis on the recent advances, current challenges, and opportunities for further development.

\section{BIOLOGICAL AIR PURIFICATION METHODS}

\subsection{Biological Processes Relevant to Biological Indoor Air Purification}

Biological air purification methods eliminate or transform gas pollutants through the action of microorganisms or plants, for which the pollutants serve as an energy and/or carbon source for the built-up of new cell material (cellular replication) and cell maintenance. The pollutant biodegradation processes involved are generally enzymatic oxidative, where microorganisms, primarily bacteria, are the main catalyst. Biodegradation of air pollutants typically takes place by mixed microbial communities thriving in a complex ecosystem (Kennes C, Veiga, 2013; Soreanu and Dumont, 2020). The microorganisms are mostly embedded in a biofilm, a moist film of cells confined within an exopolysaccharide matrix that adheres to a surface, protects microbial communities from extreme or changing conditions and enhances communication (e.g. quorum sensing) among them. The mixed microflora living in the biofilm consists of pollutant degraders, competitors and predators, which typically have significantly different properties from free-living bacteria of the same species such as an increased resistance to 
extreme contaminant concentrations. Both bacteria and fungi are microorganisms capable of biodegrading common indoor air pollutants, while photosynthetic microorganisms such as cyanobacteria and microalgae (referred to herein as microalgae) can also fix $\mathrm{CO}_{2}($ Cervera and Gomez, 2015). Bacteria typically display relatively high growth and pollutant biodegradation rates, high tolerance to toxicity and often require a neutral $\mathrm{pH}(6-8)$ and high water-activities (> 0.9) (Hernández et al. 2010). In contrast, fungi are more tolerant to low moisture contents, low $\mathrm{pH}$ and nutrient limiting conditions. While bacteria remove most efficiently hydrophilic pollutants from the air, fungi perform better with hydrophobic compounds. On the other hand, microalgae can convert $\mathrm{CO}_{2}$ into biomass through oxygenic photosynthesis, while also being autotrophic (photosynthetic), heterotrophic and/or mixotrophic metabolisms.

The large variability in type and concentration of indoor air pollutants, because of the periodic occurrence of pollution events (cleaning/polishing, use of air fresheners, cooking, painting, smoking, etc.) and the random introduction of new pollution sources such as new electronic microorganisms should play a key role on biological indoor air treatment. The large genome devices, furniture, etc., requires treatment using microorganisms with a large functional versatility and robustness. In this context, metabolically versatile large-genome of these microorganisms includes many accessory genes encoding active substrate transport, environmental sensing, multiple catabolism, stress response and secondary metabolisms, which confers them with the ability to carry out many non-essential activities related to substrate accession and stress response. These properties are critical to colonize and survive in complex and variable environments (Guieysse and Wuertz 2012). The size of the genome is typically a respectable indicator of metabolic adaptability in bacteria, since the genome of prokaryotes holds a low quantity of non-coding genes and its coding density is rather constant. Bacteria with a genome size > $5 \mathrm{Mbp}$ are often considered large-genome microorganisms, which 
correspond typically to aerobic mesophilic bacteria. Large genomes typically host a large and effective portfolio of enzymes capable of sensing, accessing and simultaneously metabolizing a broad range of pollutants at trace level concentrations $\left(\mu \mathrm{g}-\mathrm{ng} \mathrm{L}^{-1}\right)$ which would be particularly relevant for indoor air treatment.

\subsection{Biological Based System Design Configurations}

Indoor applications often limit the size of the indoor air purifier. Plant-based (botanical)

biofiltration has received recently increased attention due to its economic, environmental and social benefits, including psychological impacts by botanic plants in an indoor space. The relatively large air purifier to room volume ratio typically required for current botanical indoor air systems restraints the development and implementation of biological air purification systems (Guieysse et al. 2008). Therefore, the design of compact indoor air purifiers with high effectiveness is a challenge for biological based systems to establish a healthy indoor environment, which requires a more complete treatment of air; that is not only VOCs, but all other pollutants including $\mathrm{CO}_{2}, \mathrm{PM}, \mathrm{CO}$ and $\mathrm{NOx}$.

Different system design configurations or combinations of different biological treatment approaches (Figure 1) may overcome this constraint and potentially other challenges such as mass transfer limitations, bioavailability, guaranteed microbial safety, control of indoor air relative humidity, and $\mathrm{CO}_{2}$-removal, while being simple and robust enough to provide longterm sustainable economic functionality with minimal maintenance.

\section{$<$ FIGURE 1>}

Plant Based Systems - The treatment of pollutants using plants (phytoremediation) is mature and often applied for remediation of contaminated soil and water polluted with organic pollutants such as hydrocarbons. Biotreatment of indoor air using potted plants has been 
extensively studied and all plants tested were shown to be capable of removing VOCs from indoor air (Wolverton 1997; Wood et al. 2006; Liu et al. 2007; Yang et al. 2009; Irga et al. 2013; Pacheco-Torgal et al. 2015). A comprehensive overview of the research on botanic plants related to indoor air quality is provided by Irga et al. (2018). While potted plants are considered passive systems that depend on the diffusion of pollutants (relatively slow for the indoor air pollutant low concentrations, especially in spaces without forced air circulation), active biotreatment systems use active ventilation (fans) to improve the removal capacity. Plant-based biotrickling filters (PBTFs) are active biotreatment systems containing hydroponic plants growing in vertical panels that eliminate maintenance difficulty related to potted plants in soil as further discussed by Soreanu et al. (2013). Although some VOCs present in indoor air can directly be taken up and further metabolised by plants, the VOCs are more extensively removed by microorganism mostly present in the rhizosphere around the roots of the plants (PachecoTorgal et al. 2015). However, the removal of carbon dioxide, sulfur dioxide, nitrogen dioxide and ozone appear to be partially or solely plant facilitated (Fikiey et al. 1981; Pacheco-Torgal et al. 2015; Oh et al. 2011; Torpy et al. 2014a). These VICs are generally taken up by the plant stomates (gaseous compound exchange pores) during daylight hours (Pacheco-Torgal et al. 2015).

217 Table 2: Overview of biological system studies for indoor air purification.

\begin{tabular}{llll}
$\begin{array}{l}\text { System } \\
\text { Design }\end{array}$ & $\begin{array}{l}\text { Airflow } \\
\text { (passive/active) }\end{array}$ & Summary of Results & References \\
& & & \\
\hline Potted Plant & Passive & VOC removal capacity has successfully been & (Irga et al. 2018; \\
& & tested for about 200 plant species in about 50 & Wolverton 1997; Wood et \\
& studies. The VOCs most investigated were & al. 2006; Yoneyama et al. \\
& BTEX and formaldehyde, but some studies & 2002; Liu et al. 2007; \\
& included acrylonitrile, trichloroethylene, & Yang et al. 2009; Irga et \\
& methanol, ethylhexanol, octane and $\alpha$-pinene. & 2013) \\
& Typically, 10-20\% TVOC et al. \\
& recorded within one hour for a plant in a 10 L & \\
& gastight glass jar. &
\end{tabular}




\begin{tabular}{|c|c|c|c|}
\hline & Passive & $\begin{array}{l}\text { Ultrafine particle (PM) reduction is illustrated } \\
\text { for nearly all plant species tested. The plant } \\
\text { foliage density as well as tree architecture } \\
\text { seems most relevant enabling a small ( } 11 \%) \text {, } \\
\text { yet statistically significant hydrophobic and } \\
\text { hydrophilic PM reduction in homes. }\end{array}$ & $\begin{array}{l}\text { (Stapleton and Ruiz- } \\
\text { Rudolph 2018; } \\
\text { Weerakkody et al. 2017) }\end{array}$ \\
\hline & Passive & $\begin{array}{l}\text { VIC removal capacity has been proven for } \\
\mathrm{CO}_{2}, \mathrm{SO}_{\mathrm{x}}, \mathrm{NO}_{\mathrm{x}} \text { and } \mathrm{O}_{3} \text {, although } \mathrm{NO}_{\mathrm{x}} \text { removal } \\
\text { may negatively affect plant health. }\end{array}$ & $\begin{array}{l}\text { (Fikiey et al. 1981; } \\
\text { Pacheco-Torgal et al. } \\
\text { 2015) }\end{array}$ \\
\hline & Active & $\begin{array}{l}\text { Enhances the flow of pollutants to the root } \\
\text { zone compared to passive systems, increasing } \\
\text { the VOC and PM removal capacity. Among } \\
\text { them around } 50 \% \text { removal of } \mathrm{PM}_{2.5} \text { and } \mathrm{PM}_{10} \text {. }\end{array}$ & $\begin{array}{l}\text { (Lohr and Pearson-Mims } \\
\text { 1996; Liu et al. 2007; } \\
\text { Wang and Zhang 2011; } \\
\text { Irga et al. 2017a; } \\
\text { Treesubsuntorn and } \\
\text { Thiravetyan 2018) }\end{array}$ \\
\hline $\begin{array}{l}\text { Plant-assisted } \\
\text { Biotrickling } \\
\text { Filter }\end{array}$ & Active & $\begin{array}{l}\text { VOC removal ( } 10-75 \% \text { in a single-pass } \\
\text { configuration) proven for BTEX, } \\
\text { methylethylketone, formaldehyde, acetone, } \\
\text { octane, } \alpha \text {-pinene, decane, ethylacetate and } \\
\text { ethylhexanol. }\end{array}$ & $\begin{array}{l}\text { (Darlington and Dixon } \\
\text { 1999; Darlington et al. } \\
\text { 2001; Llewellyn et al. } \\
\text { 2002; Llewellyn and } \\
\text { Dixon 2011; Mikkonen et } \\
\text { al. 2018; Irga et al. 2019) }\end{array}$ \\
\hline Biofilter & Active & $\begin{array}{l}\text { The removal of multiple typical indoor air } \\
\text { pollutants such as toluene and formaldehyde } \\
\text { was shown to be higher than } 90 \% \text { in a single- } \\
\text { pass configuration. A mixture of } 71 \text { VOCs } \\
\text { was tested in a biofilter inoculated with yeasts } \\
\text { with most compounds removed. }\end{array}$ & $\begin{array}{l}\text { (Ondarts et al. 2012; } \\
\text { Prenafeta-Boldú et al. } \\
\text { 2019) }\end{array}$ \\
\hline $\begin{array}{l}\text { Biotrickling } \\
\text { Filter }\end{array}$ & Active & $\begin{array}{l}\text { Formaldehyde and BTEX effectively reduced } \\
\text { (respectively } 100 \% \text { and } 65-93 \% \text { ) in a single- } \\
\text { pass configuration. }\end{array}$ & (Lu et al. 2010) \\
\hline $\begin{array}{l}\text { Membrane } \\
\text { Bioreactor }\end{array}$ & Active & $\begin{array}{l}\text { Experiments performed with both } \\
\text { microporous and dense-phase membranes } \\
\text { provided a proof of concept for different } \\
\text { VOCs and odorous compounds. }\end{array}$ & $\begin{array}{l}\text { Van Ras 2005; Lebrero et } \\
\text { al. 2013) }\end{array}$ \\
\hline $\begin{array}{l}\text { Capillary } \\
\text { Bioreactor }\end{array}$ & Active & $\begin{array}{l}\text { High removal rates ( } 13 \text { or } 17 \text { times greater } \\
\text { than those tested biotrickling filters) of } \\
\text { methanol and toluene were obtained. } \\
\text { Mass transfer capacity was studied with } \\
\text { methane as model compound showing } \\
\text { removal }>100 \mathrm{~g} \mathrm{~m}^{-3} \text { capillary channel } \mathrm{h}^{-1} \text {. }\end{array}$ & $\begin{array}{l}\text { (López De León et al. } \\
\text { 2019; Rocha-Rios et al. } \\
\text { 2013) }\end{array}$ \\
\hline $\begin{array}{l}\text { Photo- } \\
\text { Bioreactor }\end{array}$ & Active & $\begin{array}{l}\mathrm{CO}_{2} \text { reduction up to } 95 \% \text { was proven } \\
\text { alongside with the significant removal of } \\
\text { VOCs, } \mathrm{NO}_{x} \text { and } \mathrm{NH}_{3} \text {. }\end{array}$ & $\begin{array}{l}\text { (Soreanu and Dumont } \\
2020 \text { ) }\end{array}$ \\
\hline
\end{tabular}


219 Biofilters, Biotrickling Filters and Bioscrubbers - While plants assist to support and sustain

220 the active microbial community in plant-based systems, microorganisms are cultivated

221 differently in conventional biological air treatment techniques, traditionally classified as

222 biofilters, bioscrubbers, and biotrickling filters. Biofilters are systems where both the

223 microorganisms and the water phase are immobilized on the biofilter media. Bioscrubbers are

224 traditionally referred to as two separate reactor compartments with recirculating process water

225 between them. In the first reactor unit, contaminants are absorbed from the pollutant air into

226 the liquid through mass transfer. In the second unit, the dissolved contaminants are biodegraded

227 by microbes suspended in an aqueous culture broth (suspended growth biomass). Biotrickling

228 filters are typically defined as single-stage bioreactor units with a packing supporting the 229 growth of a biofilm through which a liquid containing nutrients is trickled. Thus, the absorption

230 of contaminants from the polluted air to the process liquid and their subsequent biodegradation

231 in biotrickling filters take place in one process unit. The microbes are mostly immobilized on

232 the packing (fixed-film biomass). These conventional gas treatment systems have been

233 developed and applied for many industrial applications since the late 1950s. They are recognised as reliable and economical control techniques for treating gaseous stream with relatively low concentrations of contaminants (Kennes and Veiga 2013; Soreanu and Dumont 2020; van Groenestijn and Kraakman 2005; Estrada et al. 2011), but more research is needed at the even lower concentrations common in indoor spaces.

Membrane Bioreactors - These bioreactors for gas treatment use membranes that separates the contaminant-laden gas stream and the process liquid containing the microorganisms and nutrients required for pollutant degradation. A biofilm of microorganisms develops on the membrane at the liquid side and the air pollutants diffuse from the gas stream through the membrane to the biofilm. Biological based air treatment systems using membranes are of interest for indoor air purification because of its multiple advantages compared to their 
biological counterparts. The first advantage is that the biofilm does not interfere with the gas stream and that the biomass optimal environmental conditions can be controlled in terms of water activity and nutrient supply. Secondly, this configuration eliminates the risk of unintentionally drying out of the biofilm and prevents moisture and microorganisms being released from the air purification system with certain membrane types (e.g. thin dense-phase dimethylsiloxane membranes). Finally, hydrophobic indoor air pollutants with high membrane permeability may be treated more effectively as further discussed by Kumar et al. (2008) and Studer and Von Rohn (2008).

Capillary Bioreactors - Capillary reactors are small channels where capillary forces become dominant relative to gravity forces. The small channels (capillary channels) can be used to create a train of alternating liquid and air bubbles flowing co-currently. The optimal flow pattern is called segmented flow or Taylor flow in a specific gas to liquid ratio and alternating frequency. The flow patron creates internal liquid circulation that enhances the mass transfer between the gas and the liquid phase. This plug flow contains no macromixing or axial dispersion while providing local internal mixing with minimum energy due to the low pressure drop over the channels (Kreutzer et al. 2005; Rocha-Rios et al. 2013). Capillary reactors can combine enhanced mass transfer at relatively low pressure drop, both important factors usually influencing the cost of air treatment systems. Laminar gas flow conditions are typically observed in biological gas treatment system and therefore highly dependent on diffusion rate of molecules (rather than advection), which is especially slow in liquids. Improving advection (e.g. by intense mixing) will increase the mass transfer especially through the liquid phase. The flow characteristics in capillary channels has been researched in the framework of chemical reaction optimisation (Kreutzer et al. 2005; Shao et al. 2010) and recently also studied for biological gas treatment (Rocha-Rios et al. 2013; López De León et al. 2019). 
268 Photobioreactors - Microalgae in photobioreactors fix $\mathrm{CO}_{2}$ using light energy with an

269 associated release of oxygen. It represents a viable solution for the continuous control of elevated $\mathrm{CO}_{2}$-concentrations of indoor air in spaces with many occupants such as office buildings or schools. Microalgae can convert $\mathrm{CO}_{2}$ into biomass through photosynthesis, while also being capable of improving air quality by degrading or bioconverting hydrocarbons as some species exhibit a versatile autotrophic, heterotrophic or mixotrophic metabolism. Both microalgae and botanical plants are based on oxygenic photosynthesis, but microalgae are much more efficient in converting light into biomass due to their small cells and suspended growth in a liquid environment (Brennan and Owende 2010). With over 50,000 species of microalgae identified, the knowledge on microalgal cultivation has notably increased recently, many microalgae studies being carried out with the focus on biofuel production, wastewater treatment and food production. The most used microalgae species are Spirulina (Arthrospira), Chlamydomonas, Scenedesmus and Chlorella sp. because they are known to be robust against contaminants, being easy to grow, nontoxic, edible and of which the first now is commonly used as a dietary supplement. Key environmental conditions for $\mathrm{CO}_{2}$-fixation by microalgae are light availability and temperature. $\mathrm{CO}_{2}$-conversion increases with the intensity of light provided until the microalgae culture becomes light saturated, corresponding to light intensities of about $10 \%$ of the summer and $20 \%$ of the winter light brightness for most microalgae (Richmond and $\mathrm{Hu} 2013$ ). The optimal temperature commonly ranges from 15 to $30^{\circ} \mathrm{C}$ (Zhou et al. 2017). Photo-bioreactors have been studied and tested for different applications including flue gas treatment from coal power plants (Mendoza et al. 2013), combined treatment of exhaust gas and wastewater (Anbalagan et al. 2017), biogas upgrading (Rodero et al. 2019) and fully enclosed spaces such as permanently occupied space stations (Niederwieser 2015; Soreanu and Dumont 2020). The applicability of microalgal systems for indoor air treatment 
is underdeveloped, as common conditions and the concentrations of indoor air pollutants are far from those of industrial systems.

\subsection{Examples of Commercial Bio-based Indoor Air Systems}

The market of biological purification systems for improving indoor air quality is rapidly expanding, but only a few commercially available plant-based systems have proven to have a high and long-term removal efficiency for relevant VOCs such as formaldehyde (Torpy et al. 2014b). Green walls are not necessarily installed to control the indoor air quality but are an illustration of interior landscaping and are popular in office buildings mostly because they enhance the aesthetics and may help align company brands with dedication to sustainability. Figure 2 a shows an example of an aesthetic green wall consisting of moss requiring no extra light or regular watering while adsorbing sound (Ambius 2020).

The availability of multiple design concepts using botanical and microbial approaches is clearly promising and deserves to be further investigated. Different system types may have to be developed, ranging from personal mobile air purifiers (Andrea 2020), as shown in Figure 2b, to larger building air purifiers fully integrated with the HVAC system of building, as shown in Figure $2 \mathrm{c}$, where air is circulated through a vertical green wall consisting of plants in a porous rooting material (Nedlaw Living Walls 2020). Maintaining optimal moisture control is critical and automated moistening when a fan pulls air through the plant root zone would be important as incorporated by Phytofilter in their active potted plant air purifier system (Phytofilter 2020). Remote monitoring using sensors and management performing plant care including providing water, light and ventilation may be used to facilitate the management of active green walls in its specific building environment. These basic functions may be combined with a series of critical conditions such as temperature and relative humidity $(\mathrm{RH})$ as well as carbon dioxide and certain VOCs as proposed and tested by Liu and colleagues (2018). 
317 Hybrid systems still need to be developed for a more complete treatment of indoor air; that is not only VOCs, but all other pollutants including $\mathrm{CO}_{2}, \mathrm{PM}, \mathrm{CO}$ and $\mathrm{NOx}$, so that it can fully contribute to a better indoor air quality.

\section{<FIGURE 2>}

\section{CHALLENGES FOR BIOLOGICAL INDOOR AIR PURIFICATION}

Conventional chemical-physical methods for indoor air purification are, besides the shortcomings mentioned above, also disadvantaged by the diversity and variability in space and time of pollutants in indoor environments. This is an opportunity for biological systems, which can make use of diverse and adaptive microbial communities capable of removing pollutants. These adaptive characteristics have been consistently observed in industrial biofilters successfully treating low concentrations of, often odorous, emissions from different sources with varying concentrations over time (Kennes and Veiga 2013; Soreanu and Dumont 2020; van Groenestijn and Kraakman 2005; Estrada et al. 2011). Although microorganismsbased biological abatement has mostly been focussed on the treatment of VOCs and odours, indoor botanical plants have been shown capable of removing also some VOCs (Irga et al. 2018), nitrogen dioxide (Coward et al. 1996; Yoneyama et al. 2002), sulfur dioxide (Lee and Kim 1999), as well as ozone (Fikiey et al. 1981) and even particulate matter as demonstrated by Lohr and Pearson-Mims (1996). While biological methods for the abatement of industrial off-gases are reasonably developed, the potential for indoor pollutant abatement is currently emerging (Pacheco-Torgal et al. 2015; Vallero 2011).

Biological indoor air purifying systems are considered a 'green' technology that can boost the eco-efficiency of smart-buildings and bring extra advantages as to aesthetics and Indoor Environmental Quality (IEQ). This may only be possible when overcoming some of the 
guaranteed microbial safety, elevated indoor air relative humidity, and incorporate $\mathrm{CO}_{2}-$ removal. In addition, system economic feasibility and reliability are a prerequisite to enable practical implementation and sustain guaranteed performances.

\subsection{Bioavailability and Mass transfer Limitations}

Bioavailability is an expression of the fraction of the pollutant mass present in a compartment that has the potential of being assimilated by the organism (Vallero 2011). Contaminants with high solubility in water such as alcohols and aldehydes are readily removed from the air by biological air filtration, while other pollutants such as long-chain hydrocarbons, with low aqueous solubility, may require an enhancement of the biofiltration performance. In addition, the low concentrations of indoor air contaminants typically cause increased mass transfer limitations and thus a reduced bioavailability for effective removal. One major downside of biological indoor air cleaning systems is the large value of the biological purifier volume to room ratio required due to the high footprint cost of buildings. For instance, an indoor air biological purifier for a room with dimensions $8 \mathrm{~m} \times 5 \mathrm{~m} \times 2.5 \mathrm{~m}(\mathrm{~L} \times \mathrm{W} \times \mathrm{H})$ would require a relatively large volume of about 1100 - 3300 litres, assuming the typical gas residence time of 10 - 30 seconds of industrial applications for a 95\% removal efficiency and an room air exchange rate of four per hour, which equals a purifier volume of $1-3 \%$ of the total room volume (Guieysse et al. 2008). Therefore, it may be challenging for biological based systems to obtain effective indoor air cleaning performances that is reasonably compact in size.

Besides overcoming mass transfer limitations, biological indoor air purification systems also need to be able to sustain enough microbial activity under conditions of trace pollutant concentrations. Pollutants are utilized by microbes to obtain energy and synthesize new biomass, but when pollutant concentrations are low such as in indoor air, and due to the variability may decrease even lower, a critical level can be reached below the production of 
new microbial cells is not good feasible. Attached growth (biofilms) are known to be able to support biomass under changing conditions including carbon and energy source depletion. A typical result of the biomass switching into starvation mode is the removal of cells from a biofilm (dispersal) mediated by the decrease in bacterial adhesiveness and biodegradation of the biofilm matrix (Madigan et al. 2017). Indoor air pollutants may not always be high enough in energy and/or carbon content essential for cell maintenance and growth, and co-metabolism may be required for an effective pollutant removal. As low concentrations are common in the environment, it is relevant to note it is known that microorganisms can develop survival strategies, such as quickly increasing their substrate affinity, changing to metabolic mineralisation or accumulating the limiting substrate when possible (Madigan et al. 2017; Kovárová-Kovar and Egli 1998). The evaluation of pollutant biodegradation at the $\mu g \mathrm{~L}^{-1}-\mathrm{ng}$

$\mathrm{L}^{-1}$ level consistently showed that microorganisms can mineralize pollutants down to $\mathrm{pg}^{-1}$ and that the so-called affinity constant determined at higher concentrations are at trace levels differently (Subba-Rao et al 1982).

\subsubsection{Fundamentals of Gas-Liquid Mass Transfer in Bioreactors}

Two processes are occurring simultaneously in biological air purification systems. The first step is the transfer of the gas pollutant from the air to the biofilm or aqueous cultivation broth, after which the second step, biological degradation of the pollutants, can occur. These processes of mass transfer and biological degradation occur almost instantaneously, typically rate limited by either the mass transfer or the bio-kinetics. Since biological gas treatment techniques are typically most practical at relatively low concentrations, at least partial mass transfer limitation can be expected (Kennes and Veiga 2013; Kraakman et al. 2011). This limitation is further triggered by the hydrophobic nature of a fraction of indoor air pollutants ( $\mathrm{CO}, \mathrm{NO}_{2}$, aromatic and aliphatic hydrocarbons, cycloalkanes, halocarbons, terpenes, etc.), 
which hinders their mass transport from the air emission to the micro-organisms which are often surrounded by a moist (hydrophilic) environment.

Mass transfer of gas pollutant or oxygen can be limiting and may occur at different locations of the reactor such as near the liquid/biomass interface, inside the biofilm, or near the outlet of the reactor due to the low residual concentrations in the gas phase. Mass transfer can be described with the theory of Lewis and Whitman (Lewis and Whitman 1924). This two-film model uses two phases (e.g. air and water) that have not reached equilibrium as to Henry's law. Such an equilibrium only exists at the direct air-water interface, while the target pollutant transfers to or from this interface with a specific rate. This transfer rate is determined by the pollutant properties and the air and water properties and is defined with mass transfer rate coefficients. The overall mass transfer coefficient ( $\left.k_{\text {overall }}\right)$ can be simplified to a mass transfer rate coefficient of different parts of the system, as shown in Eq. (1).

$$
1 / \mathrm{k}_{\text {overall }}=1 / \mathrm{kG}_{\mathrm{G}}+1 / \mathrm{k}_{\mathrm{L}}+1 / \mathrm{k}_{\mathrm{B}}
$$

Where $\mathrm{kG}_{\mathrm{G}}, \mathrm{kL}_{\mathrm{L}}$ and $\mathrm{k}_{\mathrm{B}}$ are the mass transfer rate coefficients for respectively the gas phase, the liquid phase and the biofilm. Mass transfer coefficients are not only determined by physicalchemical properties of the pollutant and the air and liquid media, but also the reactor type and its operating conditions (Kim and Deshusses 2008; Dorado et al. 2009; Kraakman et al. 2011). Mass transfer limitation have been observed in the gas phase under laminar gas flow conditions and low pollutant concentrations (van Ras et al. 2005) as well as between the liquid phase and biofilm under turbulent conditions and high pollutant concentrations (Estrada et al. 2014). However, under the most common conditions the mass transfer resistance in the gas and the biofilm can be expected to be negligible. Therefore, the overall mass transfer rate per reactor volume $\mathrm{R}\left(\mathrm{g} \mathrm{m}^{-3} \mathrm{~s}^{-1}\right.$ ) from the gas to the liquid phase may be described by Eq. (2) (Koch 1990).

$$
\mathrm{R}=\mathrm{kLa}\left(\mathrm{C}_{\mathrm{G}} / \mathrm{H}-\mathrm{C}_{\mathrm{L}}\right)=\left(\mathrm{D}_{\mathrm{AL}} / \delta_{\text {film }}\right) \mathrm{a}\left(\mathrm{C}_{\mathrm{G}} / \mathrm{H}-\mathrm{C}_{\mathrm{L}}\right)
$$


where $\mathrm{D}_{\mathrm{AL}}$ is the gaseous pollutant diffusivity in the liquid $\left(\mathrm{m}^{2} \mathrm{~s}^{-1}\right), \mathrm{H}$ the Henry coefficient

418 (dimensionless) and $\delta_{\text {film }}$ the liquid film thickness $(\mathrm{m}) . \mathrm{C}_{\mathrm{G}}$ the gas pollutant concentration $(\mathrm{g}$ $\mathrm{m}^{-3}$ ) and $\mathrm{C}_{\mathrm{L}}$ the liquid phases pollutant concentrations. The term $\mathrm{k}_{\mathrm{La}}\left(\mathrm{s}^{-1}\right)$ is a volumetric coefficient that determine the mass transfer rate by factors independent of the concentration, where $\mathrm{k}_{\mathrm{L}}$ is the liquid phase mass transfer coefficient $\left(\mathrm{m} \mathrm{s}^{-1}\right)$ and " $\mathrm{a}$ " is the specific gas-liquid interfacial area $\left(\mathrm{m}^{2} \mathrm{~m}^{-3}\right)$.

Pollutant mass transfer takes place through both diffusion and advection. Diffusion is the random Brownian motion of individual pollutants in a medium, while advection is the largerscale motion of the medium containing the pollutants. The mass transfer enhancement in gasliquid pollutant exchange reactors usually requires an intensification in power consumption through boosted mixing or increased turbulence. Unlike turbulent systems (e.g. aerated stirred tanks) where the suspension of air-liquid-cells can be assumed a well-mixed system with mass transfer expected to be comparable throughout the reactor, in laminar contactors (e.g. biofilters for air treatment) heterogeneities caused by pollutant gradients as well as irregular moisture content and biomass concentrations may create limitations for optimum mass transfer. Fundamental processes like mass transfer in the heterogenic biological air purification systems are more difficult to describe mathematically, which is desired to fully understand the ratelimiting steps in a system and eliminating a design of the bioreactor that is primarily based on empirical experience (Popat and Deshusses 2010).

\subsection{Microbial Safety Challenges}

The potential formation of microbial air pollutants (harmful bioaerosols) may be considered a potential drawback of biological air purification systems. Bioaerosols refer to both living and non-living components, for example pollen, dust, spores, mites, allergens, viruses, bacteria and fungi. Bioaerosols contaminate the air via pets, mould, insects, sick occupants, (de)humidifiers 
or improper air filters and may be attached to dust particles. Potted plants may also contribute

to indoor bioaerosols (Soreanu and Dumont 2020). Air contaminated with bioaerosols may cause allergic reactions and infectious diseases. In addition, indoor environments can generate conditions that can amplify certain microbial species including pathogens and may include aerosols from plumbing, wetted surfaces or damp indoor environments. Conditions supporting the accumulation of stagnant water is for example known to allow the proliferation of Legionella. Legionella growth requires, besides stagnant water, a carbon source and a temperature around $38^{\circ} \mathrm{C}$ (Grimes 1991). However, although the proliferation and transmission of Legionella is limited under typical indoor space temperatures (Burchett et al. 2007), increased temperatures may occur as a result of lighting systems or integrated water recirculation pumps. Hence, an indoor air purifying system needs to eliminate the risks of nuisance due to the release of harmful bioaerosols.

Normally fungal amplification in indoor spaces such as bathrooms is primarily caused by elevated room humidity levels above about 80 \% RH (Adan and Samson 2011). Biological systems require a high water-activity near the active zones to sustain microbial activity, which holds the risk of increasing the $\mathrm{RH}$ of the air treated in indoor rooms, where $\mathrm{RH}$ of $30-60 \%$ is common for comfort. In addition, too many plants in one room potentially may increase the $\mathrm{RH}$ beyond the comfort zone and entails an associated risk due to mould development (Darlington et al. 2001; Llewellyn et al. 2008).

In addition, spores can be produced which may involve reproductive cells of plants, fungi or algae as part of their life cycle as well as bacterial cells adapted in adverse conditions for dispersal and/or survival. Spores are hardy and typically inactive and may require more aggressive conditions to control or contain compared to active microbial cells.

Besides the potential for the proliferation of microbial species and spores, the amplification of microbial products can also be a source of diseases and may involve volatiles or other microbial 
metabolites including toxics. For example, many indoor fungi produce metabolites that can induce respiratory or allergic diseases upon exposure. Several hundred of mycotoxins have shown to be potentially harmful with respect to food contamination (Alshannaq and Yu, 2017), while the effects of inhalation of indoor-related mycotoxins are far less clear at this moment (Korkalainen et al., 2017). These microbial toxins are typically odourless and can be released even from dead microbial material.

\subsubsection{The Risk of Microbial Emissions}

Relatively dry conditions in a biological air treatment system stimulating the growth of fungi may increase the risk of fungal spore release (Pasanen et al. 1991), a focus of interest because they may possess multiple hazard potential for human health (allergies, toxicosis, infections). Irga et al. (2017b) assessed an active green wall and concluded that active botanic biofilters are unlikely to release fungi to hazardous levels if the system is maintained properly. Darlington and colleagues did observe increased fungal spores in the indoor air during the first year of operation of a moss biofilter using lava rock a support media but remained within typical reported fungal counts of indoor spaces such as flats containing house plants (100-200 CFU $\mathrm{m}^{-3}$ ), considered a healthy level (Darlington et al. 2000). This was more recently confirmed by Fleck et al. (2020) who concluded that fungal spores are emitted in concentrations well below WHO safety guidelines from active green walls when operated under well monitored conditions. Some organisms present in buildings may have infectious potential, but some are not highly virulent and rarely cause infection in people with healthy lungs and healthy immune systems. Moreover, a study by Ibanga et al. (2018) on an industrial biofilter treating odorous foul air from a Material Recovery Facility showed that organic biofilters containing woodchipbased media can remove bioaerosols. The average removal of the four clusters of bioaerosols studied, total fungi, total mesophilic bacteria, Aspergillus fumigatus and Gram-negative bacteria, accounted for $71 \%, 68 \%, 70 \%$ and $50 \%$, respectively, regardless of the gas contact 
time tested in the biofilter. Although the emitted bioaerosols concentrations from the biofilter still exceeded ambient background concentrations, the results confirm earlier studies by Becker and Rabe (1997) that measured a 69\% and 89\% reduction in Aspergillus fumigatus spores from an industrial biofilter treating foul air from an indoor composting facility. Although the risk of elevated spore concentrations in the treated air from biological systems may seem limited (and not much more than background indoor air concentrations), there is however still too little data available in the case of faulty equipment or unforeseen upsets.

The risk of elevated concentrations of secondary products like volatiles or other microbial metabolites including toxics in biological air purification systems is currently unclear and would require further study. Endotoxins and mycotoxins may also be more difficult to remove in biological filters. A study evaluating the effectiveness of various types of biofilter media to purify the ventilation air from a chicken hatchery room reveal that endotoxic was only slightly removed in a typical biofilter. The endotoxic removal ranged from 11 to $51 \%$, while dustparticles were moderately (about $82 \%$ ) removed and gram-negative bacteria highly (about 99\%) removed (Tymczyna et al., 2007).

Human health safety parameters need to be established for indoor air purification applications that allow the comparison of physical-chemical and biological treatment systems. As example could be used the "tolerable" level of $10^{-6}$ DALYs per person per year which was introduced in the WHO Guidelines for Drinking-Water Quality (2004) by analogy to the established "tolerable lifetime risk" for carcinogenic chemicals of 1 case of cancer per 100,000 exposed people over a 70-year lifetime. The metric DALYs for a disease or health condition are calculated as the sum of the Years of Life Lost (YLL) due to premature mortality in the population and the Years Lost due to Disability (YLD) for incident cases of the health condition. 
While the focus should always be on reducing the exposure to harmful microbes, there is also an opportunity to encourage introduction of beneficial microbes. Beneficial microbes, so-called environmental probiotics, may provide a protection against opportunistic pathogens or their expansion. Indoor airborne microbes may also be a source and passage of the diversity of human microbes, the so-called the human microbiome, that assists for example in providing nutrients for our cells and benefits the programming of our immune system and thus potentially prevent or reduce the risk of suffering diseases (The National Academies of Science 2017). Nevertheless, these hypothetic connections on human health by plants-associated microbes in biological systems such as green walls remain to be fully explored.

\section{3 $\mathrm{CO}_{2}$ as Indoor Air Pollutant}

Because occupants produce $\mathrm{CO}_{2}$, its concentration in indoor spaces occupied by humans and/or animals is higher than the concentrations outdoors. Concentrations above $1,000 \mathrm{ppm}_{\mathrm{v}}$ are defined as an indoor air pollutant by the American Society of Heating, Refrigerating and AirConditioning Engineers (ASHREA 2019) and in most green building certification schemes threshold $\mathrm{CO}_{2}$ concentrations are considered (Wei et al. 2015). With the growing trend of constructing airtight buildings to provide energy consumption savings, the difference in indoor-outdoor $\mathrm{CO}_{2}$ concentration increases as the ventilation rate per person decreases (i.e. rate of outdoor air supply to an indoor space). With the current global average outdoor concentration of about $400 \mathrm{ppm}_{\mathrm{v}}, \mathrm{CO}_{2}$ levels in urban areas can be expected to be higher

536 (Persily 1997) and $\mathrm{CO}_{2}$ concentrations inside occupied indoor spaces typically vary from outdoor levels up to several thousand $\mathrm{ppm}_{\mathrm{v}}$ (Persily et al. 2008). Elevated $\mathrm{CO}_{2}$ concentrations in office building can be expected especially in the afternoons and in meeting rooms where important decisions are sometimes made. 
540 Several studies have shown that human performance is directly influenced by the $\mathrm{CO}_{2}$ 541 concentration. Indeed, a decline in workplace productivity and student academic performance 542 have been shown with elevated $\mathrm{CO}_{2}$ levels (Satish et al. 2012; Bakó-Biró et al. 2004; Seppänen 543 et al. 2006; Shaughnessy et al. 2006). Satish et al. (2012) showed a moderate but statistically 544 significant adverse effects of $1,000 \mathrm{ppm}_{\mathrm{v}} \mathrm{CO}_{2}$ in six out of a nine scales of human decision545 making performance and a large reduction in seven scales at 2,500 $\mathrm{ppm}_{\mathrm{v}}$ when compared to a 546 baseline level of $600 \mathrm{ppm}_{\mathrm{v}}$. Two previous studies with only 10 participants showed that they 547 performed proofreading significantly more poorly at $\mathrm{CO}_{2}$ concentrations of $4,000 \mathrm{ppm}_{\mathrm{v}}$ and marginally but significant differences were recorded at 3,000 $\mathrm{ppm}_{\mathrm{v}}$ versus $600 \mathrm{ppm}_{\mathrm{v}}$. The difference in reading performance was observed in the errors found, not in the reading speed. The quality of sleep is also affected by the $\mathrm{CO}_{2}$ concentration in the sleeping room, alongside the freshness of the sleeping room air perceived and the next day performance (Strøm-Tejsen et al. 2016). In addition, negative symptoms like dry eyes, sore throat, nose congestion (related to the mucous membranes) and drowsiness, short breath, cough and panting (related to the lower respiratory tract) have been associated with elevated $\mathrm{CO}_{2}$ levels (Erdmann and Apte 2004).

556

Although many elevated $\mathrm{CO}_{2}$ concentrations are the result of insufficient supply of ambient outside air as per current professional standards, even the ventilation rates in the leading ASHRAE standard (ASHREA 2019) can result in $\mathrm{CO}_{2}$ concentrations higher than $1,000 \mathrm{ppm}_{\mathrm{v}}$ in generously occupied spaces (Satish et al. 2012).

560

561 
To overcome mass transfer limitations, several strategies may be considered. Enzymatic transformations outside the cell to facilitate mass transfer have been suggested as a microbial mechanism to explain extremely high performances of conventional biofilters treating hydrophobic pollutants (Miller and Allen 2005). In addition, direct pollutant uptake from the air under dry conditions has been shown in fungal-based systems (Arriaga and Revah 2005; Vergara-Fernández et al. 2006; Lebrero et al. 2016). The use of bioactive polymeric coatings that hold a high affinity for the target pollutant has been shown to enhance pollutant uptake from the air emission in packed bed bioreactors, thus avoiding any mass transfer required through the water layer covering conventional biofilms. This biocatalytic approach has been shown with biocatalytic activity being retained for months under growth-limiting conditions

574 (Flickinger et al. 2017; Estrada et al. 2015). Moreover, extracellular metabolites such as biosurfactants can enhance the mass transfer of gas pollutants (Albino and Nambi 2009) or the addition of chemical surfactants as shown by Song et al. (2012).

New reactor designs can also provide enhanced mass transfer with minimum power consumption, with the examples of hollow-fibre membrane bioreactors, capillary bioreactors

579 or two-liquid phase partitioning bioreactors. Hollow-fibre membrane bioreactors use membranes that separates the contaminant-laden gas stream from the process liquid containing the microorganisms. Hydrophobic indoor air pollutants with high membrane permeability may be treated more effectively as the hydrophilic barrier (water) can be avoided. Capillary reactors are small channels where capillary forces become dominant relative to gravity forces. These small channels can be used to create a train of alternating liquid and air bubbles flowing cocurrently. This flow patron can create internal liquid circulation that enhances the mass transfer between the gas and the liquid phase. Two-liquid phase partitioning bioreactors (TPPBs) are employed with a non-aqueous liquid phase that is water-immiscible and non-volatile (e.g. 
specifically to overcome limitations of mass transfer (Muñoz et al. 2012). Direct uptake of the hydrophobic target pollutant from the silicon oil by micro-organisms at the oil-water interface is assumed the mechanism for improved performance. A non-aqueous liquid phase may also provide buffer capacity against starvation periods or pollutant surges by providing a VOC reservoir, which in addition may result in enhanced process stability and system reliability (Darracq et al. 2009).

Besides overcoming mass transfer limitations, biological indoor air purification systems also need to be able to sustain enough microbial activity under conditions of trace pollutant concentrations. Indoor air pollutants may not always be high enough in energy and/or carbon content essential for cell maintenance and growth, and co-metabolism may be required for an effective pollutant removal. The bioactive zones of plants (i.e. soil, plants roots and plant leaves) can provide extra energy and carbon substrates to sustain overall microbial eco-system stability, while hydroponic substrates may be used as secondary substrate in plant-based systems for biological indoor air purification systems (Guieysse et al. 2008; Soreanu et al. 2013).

\subsection{Bio-based Hybrid System:}

\subsubsection{Capillary Reactor Combined with a Botanical Green wall}

As mentioned before, hybrid systems combining several technologies may be more suitable for effective indoor air purification. A capillary reactor could be combined with an existing vertical green wall so that the process liquid from the capillary reactor is fed to the root zone of the plant in the green wall (Figure 3). The advantage of such a combination is that the benefits of the plant-based green wall such as aesthetics and support of microbial activity (through root exudates produced by photosynthesis that enhances mutual benefit between plant and microbes) are combined with the high mass transfer capacities of a capillary reactor. 
614 This hybrid system could be obtained using existing vertical green walls that use a hydroponic 615 substrate with a recirculation water flow so that one liquid stream is combined in the two

616

617

618

619

620

621

622

623

624

625

626

627

628

630

631

632

633

634

635

636

637

638 systems. It is estimated by the authors that the size, materials and labour involved in installing a green wall will be significantly greater compared to adding a capillary reactor. The additional costs would be limited to the capillary reactor that might require an additional liquid flow regulating valve and a separate air ventilation device to control the liquid and air flow through the capillary reactor. This hybrid system could advance existing (mainly aesthetic) green walls and foster HVAC energy savings.

\section{<FIGURE 3>}

\subsubsection{UV Photolysis-Based Systems}

Combining a biological purifier with ultraviolet (UV) photolysis for the removal of bioaerosols may be a simple solution to polish the biologically treated air under all conditions. UV photolysis-based removal of bioaerosols has been proven effective at UV light wavelengths of 200 to $280 \mathrm{~nm}$. UV disinfection has been widely used in hospitals and health care facilities, drinking water industry, food industry, wastewater treatment industry and pharmaceutical industry as a rather environmentally friendly technology (Chuaybamroong et al. 2010; Hu et al. 2020).

Viruses are most susceptible to UV radiation, while bacteria and fungal spores are more resistant to UV inactivation (ASHRAE 2009). Biofilters post-treatment to control spores and bioaerosols has been investigated by Valdez-Castillo et al. (2019), who reported 70\% inactivation efficiency of bioaerosol in a photocatalytic post-treatment with an active catalyst $\mathrm{ZnO} /$ Perlite, while Saucedo-Lucero et al. (2014) observed a spore deactivation efficiency of 98\% from a fungal biofilter with photolytic and photocatalytic post-treatment processes. 
639 Alternatively, the use of silver-based nanomaterials known for their antimicrobial properties 640 might be useful as coating or filter fabric in a post-treatment air purification device after a 641 biological purifier (Deshmukha et al., 2018).

\section{4.2.3. Membrane Bioreactors Combined with a Botanical Green Wall}

643 Bacterial emission from an innovative biofiltration system was studied by Lu et al. (2012), where the active bacteria were immobilised (embedded in calcium alginate gel). Although the air velocity was much lower $\left(0.01 \mathrm{~m} \mathrm{~s}^{-1}\right)$ than can be expected in building air conditioning systems, an effective formaldehyde biodegradation $(69-94 \%)$ was obtained with no bacterial release detected. Alternatively, dense-phase membranes may be used in biological indoor air purification systems, which have been investigated for space applications and showed the potential for an effective pollutant removal, while eliminating the release of bioaerosols and moisture in the air (van Ras et al. 2005; Soreanu et al. 2013; Kumar et al. 2008; Llewellyn et al. 2008; Kraakman et al. 2007). The use of small membranes through the root zone of botanical plants in a so-called botanical-membrane hybrid biofilter was proposed by Llewellyn et al. (2008). Similarly, a membrane bioreactor using dense-phase membranes could be combined with an existing vertical green wall that uses a hydroponic substrate so that the process liquid from the membrane bioreactor could be fed to the root zone of the plant in the green wall and support for microbial activity are combined with a limited release of bioaerosols and moisture to the ambient air.

659

<FIGURE 4>

661 
The use of biology to remove indoor $\mathrm{CO}_{2}$ offers opportunities that have received limited research attention, while indoor plants have proven to be able to reduce $\mathrm{CO}_{2}$ in indoor environments. Oh et al. (2011) and Pennisi and van Iersel (2012) studied the capacity of several indoor plant species to reduce $\mathrm{CO}_{2}$ and concluded that an impractical large quantity of indoor plants would be needed due the limited photosynthetic rate to significantly reduce the indoor $\mathrm{CO}_{2}$ concentration. Plant-based green wall technology increases the efficiency of capturing $\mathrm{CO}_{2}$ compared to passive potted plants, because plant density and thus photosynthetic rate increases, along with the ease to increase the light intensity (Torpy et al. 2014b). Microalgae in photobioreactors devoted to indoor air treatment can reduce $\mathrm{CO}_{2}$ levels more effectively than higher plants as photosynthetic rates are higher due to their small cell and suspended growth in a liquid medium. Heterotrophic-phototrophic symbiotic relationships such as those observed in plant root systems offer opportunities for a more complete indoor air purification that includes $\mathrm{CO}_{2}$ removal. Combined algae-bacterial biotreatment systems or mixotrophic algae can offer opportunities for indoor air purification comparable to those found in wastewater treatment (Anbalagan et al. 2017). Up till now, microalgal cultivation has been mainly focussed on green energy and food/fine chemicals production and did not fully explore the potential for the purification of air pollutants. Soreanu and co-workers showed that $\mathrm{CO}_{2}$ can be removed up to $95 \%$ at inlet $\mathrm{CO}_{2}$ concentrations of about $400 \mathrm{ppm}_{\mathrm{v}}$ with a sparged photobioreactor, alongside with the removal of VOCs, $\mathrm{NO}_{x}$ and $\mathrm{NH}_{3}$ (Soreanu and Dumont 2020). Microalgae are capable of biotransforming VOCs, able to use $\mathrm{NO}_{\mathrm{x}}$ and indirectly assimilate $\mathrm{SO}_{\mathrm{x}}$ (Giordano and Wang 2017). The development of microalgae photobioreactors for indoor air purification may have to explore different reactor configurations, including combinations of traditional tubular algae bioreactors with air lift reactors, membrane bioreactors, capillary reactors or biotrickling filters and deserves further research to explore their full potential in the context of indoor air purification. At this point it should be stressed 
704

705

706

707

708

709

710

711

that the combination of attractive photobioreactors and illumination designs, together with the aesthetic of microalgae culture, represents a competitive advantage of this technology in indoor applications. The microalgae reactor could be combined with an existing vertical green wall that uses a hydroponic substrate so that the process liquid from the microalgae bioreactor could be feed the root zone of the plant in the green wall as illustrated in Figure 5. It is estimated by the authors that the size, materials and labour involved in installing a green wall will be significantly greater compared to adding a photo bioreactor. The additional costs would be limited to the photo bioreactor, additional liquid stream piping and valving and a separate air ventilation device to control the air flow through the photo bioreactor. This hybrid system could advance existing (mainly aesthetic) green walls and could provide $\mathrm{CO}_{2}$ removal more effectively. The additional light requirements as well as the potential release of excess moisture into the indoor environment brought about by the intensive air sparging typically applied in photo-bioreactors should be considered (Cervera and Gomez, 2015).

\section{<FIGURE 5>}

\section{BENEFITS OF BIOLOGICAL INDOOR AIR PURIFICATION}

\subsection{Building Energy Costs Savings}

Building ventilation desires the intake of fresh outdoor air, which will need to be heated or cooled in order to meet indoor requirements for temperature and humidity. Ventilation of buildings with 'fresh' ambient air only or ventilation in combination with air cleaning methods can be used to maintain or improve IAQ. However, to obtain heating and cooling energy cost savings a reduced intake of outdoor air is desired with buildings better sealed against the outside climate conditions. A reduction in outdoor air intake without compromising IAQ can 
only be obtained when low levels of all relevant pollutants can be maintained, that is for all relevant VOCs, PM and VICs, including $\mathrm{CO}_{2}$. Hybrid systems such as advanced botanicalmicrobial or combined biological-physical systems may be able to provide a more complete treatment of indoor air providing an opportunity for building energy cost savings without compromising the IAQ.

The performance of air treatment systems is usually evaluated by the removal efficiency of pollutants of a single pass through the system (the difference in concentration between inlet and outlet air assuming no significant change in pressure and temperature in the treated air) at a specific loading rate (the amount of pollutant removed over time, typically expressed per system volume). Rather than the single pass purification efficiency, the overall purification capacity per volume of indoor space is more important for indoor air purification systems. The clean air delivery rate (CADR) is the reduction in outdoor air intake that can be obtained with an indoor air purifying system, while maintaining low levels of pollutants in the room (Shaughnessy and Sextro 2006). Moreover, the CADR can be translated in total energy expenditure to evaluate potential costs savings for HVAC. The concept of CADR was introduced to evaluate various indoor air purification devices (Shaughnessy and Sextro 2006), where CADR is defined as the volume of purified air delivered per unit of time providing a specific air purifier refreshment capacity $\alpha\left(\mathrm{h}^{-1}\right)$ for an indoor room:

$$
\alpha=\mathrm{CADR} / \mathrm{V}=\eta \cdot \mathrm{Q} / \mathrm{V}
$$

Where $\mathrm{V}$ is the volume of the indoor room $\left(\mathrm{m}^{3}\right), \eta$ is the single-pass removal efficiency of the purifier $(\%)$ and $\mathrm{Q}$ is the airflow treated by the purifier $\left(\mathrm{m}^{3} \mathrm{~h}^{-1}\right)$.

Baseline fresh air rate for non-process conditioned spaces of three room-volumes per hour is typically recommended but is dependent of the type of room and its occupancy (AESHRAE 2019). Calculating the operating effectiveness (CADR/kW) makes it possible to compare 
ventilation with or without air purifiers and may need consideration of the air mixing performance of an air purifier as discussed further by Noh and Yook (2016).

Rodgers et al. (2013) installed an active plant-based biotrickling filter into a newly built residential house and proved significant savings in total energy expenditure for HVAC in the summer, when compared to the air-conditioning system alone. The biological system was evaluated on VOC and $\mathrm{CO}_{2}$ reduction and general climate conditions in the room such as temperature and RH. Green walls are open enough to easily move the air through the system and barely any increase in energy is required when incorporated into an existing HVAC system with most of the energy required to provide enough light to the plant (Soreanu et al., 2013). Active green walls integrated in the HVAC system can significantly reduce the intake of fresh outdoor air and have been claimed to save energy up to $60 \%$ typically used by conventional HVAC systems (Nedlaw Living Walls 2020).

\subsection{Green Building Certifications}

Biological indoor air purifiers can also provide credits towards Indoor Environmental Quality (IEQ) for green building certification schemes that stimulates to realise sustainable buildings that are healthy, energy-efficient and environmentally friendly. IEQ has a large impact on our typical modern life and requires high indoor air quality to prevent health effects such as dry eyes, headache, tiredness, allergies, respiratory infection and sick building syndrome (SBS) (Burge, 2004). While building professionals and building owners may recognise the importance of IAQ, they often do not appreciate how routine design and construction decisions can ultimately result in IAQ problems. Sustainable building creates physical structures and uses processes that are environmentally responsible and resource-efficient and take into account the full lifecycle of a building. Green building certification was introduced in Europe and the 
certification (BREEAM; in the United Kingdom), Leadership in Energy and Environmental Design certification (LEED; in the United States) and Haute Qualite Environnementale certification (HQE; in France). Many other green building schemes have been generated since that have been adapted to national environmental and economic conditions (Wei et al. 2015).

\subsection{Improvement of Indoor Comfort and Overall Well-being}

In addition to building energy cost savings and improving IEQ, biological indoor air purifying systems can contribute to occupants' mental health in indoor spaces and may directly influence human performance and productivity. IEQ is typically quantified by indoor air pollutant concentrations (e.g. $\mathrm{CO}_{2}$ concentration) and indoor climate conditions (i.e. temperature, relative humidity and air movement), while occupants' comfort and overall well-being may be quantified in terms of a physical sensation, a persons' mental state or both at the same time. Physical health has been typical quantified the physiological reactions of blood pressure and perspiration rates. Mental health can be estimated by psychological responses (e.g. verbal scale vote of occupant what he/she considers a feeling of comfort). Kim et al. (2020) showed a statistically significant negative relationship between the indoor climate and $\mathrm{CO}_{2}$ concentrations and occupants' mental health, which was determined by blood pressure and psychological responses. In this context, green plants in indoor spaces without specifically being designed to clean indoor air have already been proven to provide valuable improvements on indoor comfort and well-being, resulting in environments that are healthier and aesthetical more pleasant to work and live in. Plant may help evaporate moisture lowering the temperature, produce oxygen through photosynthesis or may help reduce sound levels as an acoustic absorption system. Vegetation has also shown to affect emotions of consumers (Tifferet and Vilnai-Yavetz 2017). Vegetation brings elements of nature inside a building that may provide spaces that could create an aesthetical pleasant environment and potentially reduce stress. 
Plant-based systems may improve worker productivity and creativity as well as comfort or perception of their indoor space quality creating a more desirable place to work (Moya et al. 2018). Maybe the further development and benefits of (biological) indoor air purifying systems should be focussed on the overall human well-being and productivity, as it may be easier to motivate people and companies than air-pollutant-related chronic health benefits that occur decades in the future (Siegel 2019).

\section{CONCLUSIONS}

The indoor concentration of air pollutions is almost always higher than the outdoor concentration of air pollutions because outdoor-sourced contaminated air enters indoor occupied spaces and combines with indoor-sourced pollutants. The threats posed by a longterm exposure to poor indoor air quality have been acknowledged in recent years as buildings are progressively sealed due to the increasingly stricter safety guidelines and against the outside environment to obtain heating and cooling energy cost savings. Many buildings now rely entirely on mechanical ventilation to recirculate indoor air with a minimized outdoor air intake, leading to the accumulation of indoor pollutants. Currently there is not a single technology that can efficiently provide a complete and satisfactory purification of indoor air. Biological systems for improving indoor air quality are promising, but challenges need to be considered to properly address the bioavailability of low pollutant concentrations, control indoor air relative humidity, guarantee microbial safety, and incorporate $\mathrm{CO}_{2}$-removal. Indoor air treatment supported by hybrid technologies such as advanced botanical-microbial or combined biological-physical systems could foster HVAC energy savings and green building certification schemes, advance existing ecstatic green walls, and enhance indoor comfort and overall wellbeing. Overall, there is an urgent need for fundamental research under relevant indoor conditions to reveal the full potential for biological indoor air purification. 


\section{Acknowledgements}

814 This work was supported by the Ministry of Science, Innovation and Universities [project

815 RTI2018-0-096441-B-I00]. The Regional Government of Castilla y León and the EU-

816 FEDER program [grant numbers CLU 2017-09 and UIC 071] are also gratefully

817 acknowledged. The financial support of EREN Castilla y León for the contract of Cristina

818 Perez is gratefully acknowledged.

\section{References}

821

Adan OC, Samson RA (2011) Fundamentals of mold growth in indoor environments and strategies for healthy living. Springer Science \& Business Media

Albino JD, Nambi IM (2009) Effect of biosurfactants on the aqueous solubility of PCE and TCE. Journal of Environmental Science and Health - Part A Toxic/Hazardous Substances and Environmental Engineering 44:1565-1573. https://doi.org/10.1080/10934520903263538

Alshannaq A, Yu JH (2017). Occurrence, toxicity, and analysis of major mycotoxins in food. International Journal of Environmental Research and Public Health 14(6). https://doi:10.3390/ijerph14060632.

Anbalagan A, Toledo-Cervantes A, Posadas E, et al (2017) Continuous photosynthetic abatement of $\mathrm{CO}_{2}$ and volatile organic compounds from exhaust gas coupled to wastewater treatment: Evaluation of tubular algal-bacterial photobioreactor. Journal of CO2 Utilization 21:353-359. https://doi.org/10.1016/j.jcou.2017.07.016

Andrea (2020) http://www.andreaair.com/. Accessed 2 May 2020

Anses (2014) Rapport d'étude de l'Anses relatif à "Étude exploratoire du coût socio-économique des polluants de l'airintérieur." CRD No 2011-CRD-11.

Ambius (2020) https://www.ambius.com/green-walls/systems/. Accessed 17 May 2020

Arriaga S, Revah S (2005) Improving hexane removal by enhancing fungal development in a microbial consortium biofilter. Biotechnology and Bioengineering 90:107-115. https://doi.org/10.1002/bit.20424

ASHRAE (2009) Indoor air quality guide. Best Practices for Design, Construction and Commissioning 
ASHRAE (2019) ASHRAE Standard 62.1. Ventilation for Acceptable Indoor Air Quality. ASHRAE Bookstore

Bakó-Biró Z, Wargocki P, Weschler CJ, Fanger PO (2004) Effects of pollution from personal computers on perceived air quality, SBS symptoms and productivity in offices. Indoor Air 14:178-187. https://doi.org/10.1111/j.1600-0668.2004.00218.x

Becker M, Rabe R (1997) Emission of fungal spores from a biofilter. Proc Int Symp Biological Gas Cleaning 221-224

Brennan L, Owende P (2010) Biofuels from microalgae-A review of technologies for production, processing, and extractions of biofuels and co-products. Renewable and Sustainable Energy Reviews 14:557-577. https://doi.org/10.1016/j.rser.2009.10.009

Broderick A, Byrne M, Armstrong S, et al (2017) A pre and post evaluation of indoor air quality, ventilation, and thermal comfort in retrofitted co-operative social housing. https://doi.org/10.1016/j.buildenv.2017.05.020

Burchett MD, Tarran J, Torpy FR (2007) Sources and avoidance of Legionnaires disease commissioned report to national indoor Plantscapers Association. University of Technology, Sydney

Burge PS (2004) Sick Building Syndrome. Occup Environ Med 61:185-190. https://doi.org/10.1136/oem.2003.008813

Cervera Sarda R and Gomez Pioz J (2015) Architectural Bio-Photo Reactors: Harvesting Microalgae on the Surface of Architecture. In: Biotechnologies and biomimetics for civil engineering F. Pacheco Torgal et al. (eds.). https://doi.org/10.1007/978-3-319-09287-4_7

Chen W, Zhang JS, Zhang Z (2005) Performance of air cleaners for removing multiple volatile organic compounds in indoor air. In: ASHRAE Transactions. pp 1101-1114

Chuaybamroong P, Chotigawin R, Supothina S, et al (2010) Efficacy of photocatalytic HEPA filter on microorganism removal. Indoor Air 20:246-254. https://doi.org/10.1111/j.16000668.2010.00651.x

Cincinelli A, Martellini T, Amore A, et al (2016) Measurement of volatile organic compounds (VOCs) in libraries and archives in Florence (Italy). Science of the Total Environment 572:333-339. https://doi.org/10.1016/j.scitotenv.2016.07.201

Coward M, Rossm D, Coward S, Cayless S, Raw G (1996) Pilot study to assess the impact of greenplants on $\mathrm{NO}_{2}$ levels in homes, building research establishment. Note N154/96. Watford, UK.

Darlington AB, Dixon MA (1999) Acetone removal kinetics by an indoor biofilter. SAE Technical Papers. https://doi.org/10.4271/1999-01-2069 
Darlington AB, Chan M, Malloch D, Pilger C, Dixon M (2000) The biofiltration of indoor air: implications for air quality. Indoor Air 10, 1. Pp 39-46. http://dx.doi.org/10.1034/j.16000668.2000.010001039.x.

Darlington AB, Dat JF, Dixon MA (2001) The biofiltration of indoor air: Air flux and temperature influences the removal of toluene, ethylbenzene, and xylene. Environmental Science and Technology 35:240-246. https://doi.org/10.1021/es0010507

Darracq G, Couvert A, Couriol C, Amrane A, Le Cloirec P, Thomas D, Dumont E, Andres Y (2009) Silicone Oil: An effective absorbent for hydrophobic Volatile Organic Compounds (VOC) removal. In: Proceedings The 3rd International Congress on Biotechniques for Air Pollution Control. Delft, the Netherlands, 28-30 September 2009, pp 215-221

Deshmukha SP, Patila SM, Mullania SB, Delekar SD (2018) Silver nanoparticles as an effective disinfectant: A review. Materials Science and Engineering 97: 954-965. https://doi.org/10.1016/j.msec.2018.12.102

Dorado AD, Rodríguez G, Ribera G, et al (2009) Evaluation of mass transfer coefficients in biotrickling filters: Experimental determination and comparison to correlations. Chemical Engineering and Technology 32:1941-1950. https://doi.org/10.1002/ceat.200900275

EEA (2019) Air quality in Europe - 2019 report. https://www.eea.europa.eu//publications/airquality-in-europe-2019. Accessed 17 September 2020

EPA (2020) https://www.epa.gov/report-environment/indoor-air-quality Accessed 22 January 2021.

Erdmann CA, Apte MG (2004) Mucous membrane and lower respiratory building related symptoms in relation to indoor carbon dioxide concentrations in the 100-building BASE dataset. Indoor Air, Supplement 14:127-134. https://doi.org/10.1111/j.1600-0668.2004.00298.x

Estrada JM, Kraakman NJR, Muñoz R, Lebrero R (2011) A comparative analysis of odour treatment technologies in wastewater treatment plants, Environ Sci Technol. 45. pp 1100-1106 http://dx.doi.org/10.1016/j.biotechadv.2012.02.010.

Estrada JM, Bernal OI, Flickinger MC, et al (2015) Biocatalytic coatings for air pollution control: A proof of concept study on VOC biodegradation. Biotechnology and Bioengineering 112:263271. https://doi.org/10.1002/bit.25353

Estrada JM, Lebrero R, Quijano G, et al (2014) Methane abatement in a gas-recycling biotrickling filter: Evaluating innovative operational strategies to overcome mass transfer limitations. Chemical Engineering Journal 253:385-393. https://doi.org/10.1016/j.cej.2014.05.053

European Commission, 2003 Indoor Air Pollution: New EU Research Reveals Higher Risks than Previously. European Commission. https://ec.europa.eu/commission/presscorner/detail/en/IP $03 \quad 1278$

European Environment Agency, 2013. Air quality in Europe-2013 Report: EEA report no 9/2013, European Union. https://doi.org/10.2800/92843 
European Directive 99/77/EC https://eur-lex.europa.eu/legalcontent/en/ALL/?uri=CELEX:31999L0077

European Directive 2010/31/EU https://www.eea.europa.eu/policy-documents/energyperformance-of-buildings-directive

Fikiey T, Ormrod DP, P OD (1981) OF OZONE, SULPHUR DIOXIDE, AND NITROGEN DIOXIDE BY PETUNIA PLANTSXXXXXXXX

Fleck R, Gill RL, Pettit T, et al (2020) Characterisation of fungal and bacterial dynamics in an active green wall used for indoor air pollutant removal. Building and Environment 179. https://doi.org/10.1016/j.buildenv.2020.106987

Flickinger MC, Bernal OI, Schulte MJ, et al (2017) Biocoatings: challenges to expanding the functionality of waterborne latex coatings by incorporating concentrated living microorganisms. Journal of Coatings Technology and Research 14:791-808. https://doi.org/10.1007/s11998-017-9933-6

Giordano M, Wang Q (2017) Microalgae for industrial purposes

González-Martín J, Kraakman NJR, Pérez C, et al (2021) A state-of-the-art review on indoor air pollution and strategies for indoor air pollution control. Chemosphere 262:. https://doi.org/10.1016/j.chemosphere.2020.128376

Grimes DJ (1991) Ecology of estuarine bacteria capable of causing human disease: A review. Estuaries 14:345-360. https://doi.org/10.2307/1352260

Guieysse B, Hort C, Platel V, et al (2008) Biological treatment of indoor air for VOC removal: Potential and challenges. https://doi.org/10.1016/j.biotechadv.2008.03.005

Guieysse B, Wuertz S (2012) Metabolically versatile large-genome prokaryotes. Current Opinion in Biotechnology 23:467-473. https://doi.org/10.1016/j.copbio.2011.12.022

Hernández M, Quijano G, Thalasso F, et al (2010) A comparative study of solid and liquid nonaqueous phases for the biodegradation of hexane in two-phase partitioning bioreactors. Biotechnology and Bioengineering 106:731-740. https://doi.org/10.1002/bit.22748

Hu X-R, Han M-F, Wang C, et al (2020) A short review of bioaerosol emissions from gas bioreactors: Health threats, influencing factors and control technologies. Chemosphere 253: https://doi.org/10.1016/j.chemosphere.2020.126737

Hubbard HF, Coleman BK, Sarwar G, Corsi RL (2005) Effects of an ozone-generating air purifier on indoor secondary particles in three residential dwellings. Indoor Air 15:432-444. https://doi.org/10.1111/j.1600-0668.2005.00388.x

Ibanga IE, Fletcher LA, Noakes CJ, et al (2018) Pilot-scale biofiltration at a materials recovery facility: The impact on bioaerosol control. Waste Management 80:154-167. https://doi.org/10.1016/j.wasman.2018.09.010 
International WELL Building Institute (2019) The WELL Performance Verification Guidebook. https://www.wellcertified.com/resources. Accessed 17 September 2020

Irga PJ, Abdo P, Zavattaro M, Torpy FR (2017a) An assessment of the potential fungal bioaerosol production from an active living wall. Building and Environment 111:140-146. https://doi.org/10.1016/j.buildenv.2016.11.004

Irga PJ, Paull NJ, Abdo P, Torpy FR (2017b) An assessment of the atmospheric particle removal efficiency of an in-room botanical biofilter system. Building and Environment 115:281-290. https://doi.org/10.1016/j.buildenv.2017.01.035

Irga PJ, Pettit T, Irga RF, et al (2019) Does plant species selection in functional active green walls influence VOC phytoremediation efficiency? Environmental Science and Pollution Research 26:12851-12858. https://doi.org/10.1007/s11356-019-04719-9

Irga PJ, Pettit TJ, Torpy FR (2018) The phytoremediation of indoor air pollution: a review on the technology development from the potted plant through to functional green wall biofilters. Reviews in Environmental Science and Biotechnology 17:395-415. https://doi.org/10.1007/s11157-018-9465-2

Irga PJ, Torpy FR, Burchett MD (2013) Can hydroculture be used to enhance the performance of indoor plants for the removal of air pollutants? Atmospheric Environment 77:267-271. https://doi.org/10.1016/j.atmosenv.2013.04.078

Kennes C, Veiga MC (2013) Air Pollution Prevention and Control: Bioreactors and Bioenergy

Kim J, Hong T, Kong M, Jeong K (2020) Building occupants' psycho-physiological response to indoor climate and $\mathrm{CO}_{2}$ concentration changes in office buildings. Building and Environment 169:. https://doi.org/10.1016/j.buildenv.2019.106596

Kim S, Deshusses MA (2008) Determination of mass transfer coefficients for packing materials used in biofilters and biotrickling filters for air pollution control. 1. Experimental results. Chemical Engineering Science 63:841-855. https://doi.org/10.1016/j.ces.2007.10.011

Koch AL (1990) Diffusion: The crucial process in many aspects of the biology of bacteria. Adv Microb Ecol 11:37-70

Korkalainen M, Täubel M, Naarala J, Kirjavainen P, Koistinen A, Hyvärinen A, Komulainen $H$, Viluksela M (2017). Synergistic proinflammatory interactions of microbial toxins and structural components characteristic to moisture-damaged buildings. Indoor Air 27(1):13-23.

Kovárová-Kovar K, Egli T (1998) Growth kinetics of suspended microbial cells: From single-substratecontrolled growth to mixed-substrate kinetics. Microbiology and Molecular Biology Reviews 62:646-666. https://doi.org/10.1128/mmbr.62.3.646-666.1998

Kraakman NJR, Ras N, Llewellyn D, et al (2007) Biological waste gas purification using membranes:opportunities and challenges. Proceedings of the Congress on Biotechniques for Air Pollution Control 331-338 
Kraakman NJR, Rocha-Rios J, van Loosdrecht MCM (2011) Review of mass transfer aspects for biological gas treatment. Applied Microbiology and Biotechnology 91:873-886. https://doi.org/10.1007/s00253-011-3365-5

Kreutzer MT, Kapteijn F, Moulijn JA, Heiszwolf JJ (2005) Multiphase monolith reactors: Chemical reaction engineering of segmented flow in microchannels. Chemical Engineering Science 60:5895-5916. https://doi.org/10.1016/j.ces.2005.03.022

Kumar A, Dewulf J, van Langenhove H (2008) Membrane-based biological waste gas treatment. Chemical Engineering Journal 136:82-91. https://doi.org/10.1016/j.cej.2007.06.006

Lebrero R, López JC, Lehtinen I, et al (2016) Exploring the potential of fungi for methane abatement: Performance evaluation of a fungal-bacterial biofilter. Chemosphere 144:97-106. https://doi.org/10.1016/j.chemosphere.2015.08.017

Lebrero R, Volckaert D, Pérez R, et al (2013) A membrane bioreactor for the simultaneous treatment of acetone, toluene, limonene and hexane at trace level concentrations. Water Research 47:2199-2212. https://doi.org/10.1016/j.watres.2013.01.041

Lee JH, Sim WK (1999) Biological absorption of $\mathrm{SO}_{2}$ by Korean native indoor plants. In: Burchett MD, Tarranm J, Wood R (ed), Towards a new millennium in people-plant relationshipsContributions from the international people-plant symposium, Sydney, July, 1998. UTS Printing Services, Sydney, pp 101-108

Lewis WK, Whitman WG (1924) Principles of Gas Absorption. Industrial and Engineering Chemistry 16:1215-1220. https://doi.org/10.1021/ie50180a002

Liu Y, Akram Hassan K, Karlsson M, et al (2018) Active Plant Wall for Green Indoor Climate Based on Cloud and Internet of Things. IEEE Access 6:33631-33644. https://doi.org/10.1109/ACCESS.2018.2847440

Liu Y-J, Mu Y-J, Zhu Y-G, et al (2007) Which ornamental plant species effectively remove benzene from indoor air? Atmospheric Environment 41:650-654. https://doi.org/10.1016/j.atmosenv.2006.08.001

Llewellyn D, Darlington A, van Ras N, et al (2008) A Hybridized Membrane-Botanical Biofilter for Improving Air Quality in Occupied Spaces. 1813

Llewellyn D, Dixon M (2011) Can Plants Really Improve Indoor Air Quality?

Llewellyn DJ, Darlington AB, Dixon MA (2002) Temperature and airflow influences indoor air biofiltration. Proceedings of the 9th International Conference on Indoor Air Quality and Climate

Lohr VI, Pearson-Mims CH (1996) Particulate matter accumulation on horizontal surfaces in interiors: Influence of foliage plants. Atmospheric Environment 30:2565-2568. https://doi.org/10.1016/1352-2310(95)00465-3

López De León LR, Deaton KE, Deshusses MA (2019) Miniaturized Biotrickling Filters and Capillary Microbioreactors for Process Intensification of VOC Treatment with Intended Application to 
Lopez de Leon, L.R., Deaton, K., Junkin, J., Deshusses, M.A. (2020) Capillary microreactors for VOC vapor treatment: Impacts of operating conditions. Chemisphere. 258: 127286. https://doi.org/10.1016/j.chemosphere.2020.127286

Lu N, Pei J, Zhao Y, et al (2012) Performance of a biological degradation method for indoor formaldehyde removal. Building and Environment 57:253-258. https://doi.org/10.1016/j.buildenv.2012.05.007

Lu Y, Liu J, Lu B, et al (2010) Study on the removal of indoor VOCs using biotechnology. Journal of Hazardous Materials 182:204-209. https://doi.org/10.1016/j.jhazmat.2010.06.016

Luengas A, Barona A, Hort C, et al (2015) A review of indoor air treatment technologies. Reviews in Environmental Science and Biotechnology 14:499-522. https://doi.org/10.1007/s11157-0159363-9

Nedlaw Living Walls (2020) http://nedlawlivingwalls.com. Accessed 26 May 2020

Niederwieser T (2015) Evaluation of a Flow-Through Test Bed for Algal Atmosphere Revitalization in Spaceflight Applications. Dissertation. Technical University of Munich

Noh KC and Yook SJ (2016) Evaluation of clean air delivery rates and operating cost effectiveness or Room air cleaner and ventilation system in a small lectura Room. Energy and Building. 199: 111-118. http://dx.doi.org/10.1016/j.enbuild.2016.03.027.

Madigan MT, Bender KS, Buckley DH, Sattle WM, Stahl DA (2017) Brock Biology of Microorganisms, 15th edition. Pearson, London

Marć M, Śmiełowska M, Namieśnik J, Zabiegała B (2018) Indoor air quality of everyday use spaces dedicated to specific purposes-a review, Environ. Sci. Pollut. Res. 25 pp 2065-2082. https://doi.org/10.1007/s11356-017-0839-8

Mendoza JL, Granados MR, de Godos I, et al (2013) Oxygen transfer and evolution in microalgal culture in open raceways. Bioresource Technology 137:188-195. https://doi.org/10.1016/j.biortech.2013.03.127

Mikkonen A, Li T, Vesala M, et al (2018) Biofiltration of airborne VOCs with green wall systemsMicrobial and chemical dynamics. Indoor Air 28:697-707. https://doi.org/10.1111/ina.12473

Miller MJ, Allen DG (2005) Modelling transport and degradation of hydrophobic pollutants in biofilter biofilms. Chemical Engineering Journal 113:197-204. https://doi.org/10.1016/j.cej.2005.03.008

Moya TA, van den Dobbelsteen A, Ottelé M, Bluyssen PM (2018) A review of green systems within the indoor environment. Indoor and Built Environment 28:298-309. https://doi.org/10.1177/1420326X18783042 
Muñoz R, Daugulis AJ, Hernández M, Quijano G (2012) Recent advances in two-phase partitioning bioreactors for the treatment of volatile organic compounds. Biotechnology Advances 30:1707-1720. https://doi.org/10.1016/j.biotechadv.2012.08.009

Oh GS, Jung GJ, Seo MH, Im YB (2011) Experimental study on variations of $\mathrm{CO}<$ inf $>2</$ inf $>$ concentration in the presence of indoor plants and respiration of experimental animals. Horticulture Environment and Biotechnology 52:321-329. https://doi.org/10.1007/s13580011-0169-6

Ondarts M, Hort C, Sochard S, et al (2012) Evaluation of compost and a mixture of compost and activated carbon as biofilter media for the treatment of indoor air pollution. Environmental Technology 33:273-284. https://doi.org/10.1080/09593330.2011.570793

Pacheco-Torgal F, Labrincha JA, Diamanti MV, et al (2015) Biotechnologies and biomimetics for civil engineering. https://doi.org/10.1007/978-3-319-09287-4_7.

Pasanen A-L, Pasanen P, Jantunen MJ, Kalliokoski P (1991) Significance of air humidity and air velocity for fungal spore release into the air. Atmospheric Environment Part A, General Topics 25:459-462. https://doi.org/10.1016/0960-1686(91)90316-Y

Pennisi SV, van lersel MW (2012) Qunatification of carbon assimilation of plants in simulated and in situ interiorscapes. HortScience 47:468-476

Persily AK (1997) Evaluating building IAQ and ventilation with indoor carbon dioxide. In: ASHRAE Transactions. pp 193-204

Persily AK, Gorfain J, Gaithersburg MD (2008) Analysis of ventilation data from the U.S. Environmental Protection Agency Building Assessment Survey and Evaluation (BASE) Study. NISTIR-7145-Revised

Phytofilter (2020) http://phytofilter.com/how-it-works/. Accessed 17 May 2020

Popat SC, Deshusses MA (2010) Analysis of the rate-limiting step of an anaerobic biotrickling filter removing TCE vapors. Process Biochemistry 45:549-555. https://doi.org/10.1016/j.procbio.2009.11.017

Prenafeta-Boldú FX, Roca N, Villatoro C, et al (2019) Prospective application of melanized fungi for the biofiltration of indoor air in closed bioregenerative systems. Journal of Hazardous Materials 361:1-9. https://doi.org/10.1016/j.jhazmat.2018.08.059

Richmond A, Hu Q (2013) Handbook of Microalgal Culture: Applied Phycology and Biotechnology, 2nd ed. John Wiley \& Sons Ltd: Chichester, UK

Rocha-Rios J, Kraakman NJR, Kleerebezem R, et al (2013) A capillary bioreactor to increase methane transfer and oxidation through Taylor flow formation and transfer vector addition. Chemical Engineering Journal 217:91-98. https://doi.org/10.1016/j.cej.2012.11.065 
Rodero MDR, Lebrero R, Serrano E, et al (2019) Technology validation of photosynthetic biogas upgrading in a semi-industrial scale algal-bacterial photobioreactor. Bioresource Technology 279:43-49. https://doi.org/10.1016/j.biortech.2019.01.110

Rodgers K, Handy R, Hutzel W (2013) Indoor air quality (IAQ) improvements using bio-filtration in a highly efficient residential home, J Green Build. 8, 1, pp 22-27

Rösch C, Kohajda T, Röder S, et al (2014) Relationship between sources and patterns of VOCs in indoor air. Atmospheric Pollution Research 5:129-137. https://doi.org/10.5094/APR.2014.016

Royal College of Physicians (2016) Every Breath We Take: the lifelong impact of air pollution. https://www.rcplondon.ac.uk/projects/outputs/every-breath-we-take-lifelong-impact-airpollution. Accessed 17 September

Satish U, Mendell MJ, Shekhar K, et al (2012) Is $\mathrm{CO}_{2}$ an indoor pollutant? direct effects of low-tomoderate $\mathrm{CO}_{2}$ concentrations on human decision-making performance. Environmental Health Perspectives 120:1671-1677. https://doi.org/10.1289/ehp.1104789

Saucedo-Lucero JO, Quijano G, Arriaga S, Muñoz R (2014) Hexane abatement and spore emission control in a fungal biofilter-photoreactor hybrid unit. Journal of Hazardous Materials 276:287294. https://doi.org/10.1016/j.jhazmat.2014.05.040

Seppänen O, Fisk WJ, Lei QH (2006) Ventilation and performance in office work. Indoor Air 16:28-36. https://doi.org/10.1111/j.1600-0668.2005.00394.x

Shao N, Gavriilidis A, Angeli P (2010) Mass transfer during Taylor flow in microchannels with and without chemical reaction. Chemical Engineering Journal 160:873-881. https://doi.org/10.1016/j.cej.2010.02.049

Shaughnessy RJ, Haverinen-Shaughnessy U, Nevalainen A, Moschandreas D (2006) A preliminary study on the association between ventilation rates in classrooms and student performance. Indoor Air 16:465-468. https://doi.org/10.1111/j.1600-0668.2006.00440.x

Shaughnessy RJ, Sextro RG (2006) What is an effective portable air cleaning device? A review. Journal of Occupational and Environmental Hygiene 3:169-181. https://doi.org/10.1080/15459620600580129

Siegel J (2019) The Future of Indoor Air: Cognitive Function, Intentional Manipulation, and Privacy. Air and Odor Management Conference and Technology Showcase, Toronto, Canada, September 19 - 20, 2019

Song T, Yang C, Zeng G, et al (2012) Effect of surfactant on styrene removal from waste gas streams in biotrickling filters. Journal of Chemical Technology and Biotechnology 87:785-790. https://doi.org/10.1002/jctb.3717

Soreanu G, Dixon M, Darlington A (2013) Botanical biofiltration of indoor gaseous pollutants - A mini-review. Chemical Engineering Journal 229:585-594. https://doi.org/10.1016/j.cej.2013.06.074 
Soreanu G, Dumont É (2020) From Biofiltration to Promising Options in Gaseous Fluxes Biotreatment. Recent Developments, New Trends, Advances, and Opportunities

Soreanu, G., Cretescu, I., Diaconu, M., Cojocaru, C., Ignat, M., Samoila, P., Harabagiu, V. (2021) Investigation of a biosystem based on Arthrospira platensis for air revitalisation in spacecrafts: Performance evaluation through response surface methodology. Chemosphere 264: 128465. https://doi.org/10.1016/j.chemosphere.2020.128465

Stapleton E, Ruiz-Rudolph P (2018) The potential for indoor ultrafine particle reduction using vegetation under laboratory conditions. Indoor and Built Environment 27:70-83. https://doi.org/10.1177/1420326X16668388

Strøm-Tejsen P, Zukowska D, Wargocki P, Wyon DP (2016) The effects of bedroom air quality on sleep and next-day performance. Indoor Air 26:679-686. https://doi.org/10.1111/ina.12254

Studer M, von Rohr PR (2008) Novel membrane bioreactor: Able to cope with fluctuating loads, poorly water soluble VOCs, and biomass accumulation. Biotechnology and Bioengineering 99:38-48. https://doi.org/10.1002/bit.21532

Subba-Rao RV, Rubin HE, Alexander M (1982) Kinetics and Extent of Mineralization of Organic Chemicals at Trace Levels in Freshwater and Sewage, Appl. Environ. Microbiol. 43, 5, pp 11391150

The National Academies of Science (2017) Engineering and Medicine, Microbiomes of the Built Environment. A Research Agenda for Indoor Microbiology, Human Health and Buildings. ISBN13: 978-0-309-44980-9

Tifferet S, Vilnai-Yavetz I (2017) Phytophilia and Service Atmospherics: The Effect of Indoor Plants on Consumers. Environment and Behavior 49:814-844. https://doi.org/10.1177/0013916516669390

Torpy FR, Irga PJ, Burchett MD (2014a) Profiling indoor plants for the amelioration of high $\mathrm{CO}_{2}$ concentrations. Urban Forestry and Urban Greening 13:227-233. https://doi.org/10.1016/j.ufug.2013.12.004

Torpy FR, Irga PJ, Burchett MD (2014b) Reducing indoor air pollutants through biotechnology. In: Pacheco Torgal F, Labrincha J, Diamanti M, Yu CP, Lee H. (ed) Biotechnologies and Biomimetics for Civil Engineering. Springer, Cham. https://doi.org/10.1007/978-3-319-09287-4_8 pp. 181210

Treesubsuntorn C, Thiravetyan P (2018) Botanical biofilter for indoor toluene removal and reduction of carbon dioxide emission under low light intensity by using mixed C3 and CAM plants. Journal of Cleaner Production 194:94-100. https://doi.org/10.1016/j.jclepro.2018.05.141

Tymczyna L, Chmielowiec-Korzeniowska A, Drabik, A (2007) The Effectiveness of Various Biofiltration Substrates in Removing Bacteria,Endotoxins, and Dust from Ventilation System Exhaustfrom a Chicken Hatchery. Poultry Science 86:2095-2100. https://doi.org/10.1093/ps/86.10.2095. 
Valdez-Castillo M, Saucedo-Lucero JO, Arriaga S (2019) Photocatalytic inactivation of airborne microorganisms in continuous flow using perlite-supported $\mathrm{ZnO}$ and $\mathrm{TiO}<\mathrm{inf}>2</ \mathrm{inf}>$. Chemical Engineering Journal 374:914-923. https://doi.org/10.1016/j.cej.2019.05.231

Vallero DA (2011) Environmental Biotechnology: A Biosystems Approach

van Groenestijn JW, Kraakman NJR (2005) Recent developments in biological waste gas purification in Europe. Chemical Engineering Journal 113:85-91. https://doi.org/10.1016/j.cej.2005.03.007

van Ras N, Krooneman J, Ogink N, Willers H, D’Amico N, di Natale C, Godia F, Albiol J, Perez J, Martinez N, Dixon M, Llewellyn D, Eckhard F, Zona G, Fachecci L, Kraakman NJR, Demey D, Michel N, Darlington A (2005) Biological air filter for air-quality control. In: Wilson, coordination, A., Elmann-Larsen, B., ESA SP-1290, ESTEC (Eds.), Microgravity Applications Programme: Successful Teaming of Science and Industry. ESA Publications Division, Noordwijk, Netherlands, ISBN92-9092971-5, pp 270-280

Vergara-Fernández A, van Haaren B, Revah S (2006) Phase partition of gaseous hexane and surface hydrophobicity of Fusarium solani when grown in liquid and solid media with hexanol and hexane. Biotechnology Letters 28:2011-2017. https://doi.org/10.1007/s10529-006-9186-4

Wang Z, Zhang JS (2011) Characterization and performance evaluation of a full-scale activated carbon-based dynamic botanical air filtration system for improving indoor air quality. Building and Environment 46:758-768. https://doi.org/10.1016/j.buildenv.2010.10.008

Weerakkody U, Dover JW, Mitchell P, Reiling K (2017) Particulate matter pollution capture by leaves of seventeen living wall species with special reference to rail-traffic at a metropolitan station. Urban Forestry and Urban Greening 27:173-186. https://doi.org/10.1016/j.ufug.2017.07.005

Wei W, Ramalho O, Mandin C (2015) Indoor air quality requirements in green building certifications. Building and Environment 92:10-19. https://doi.org/10.1016/j.buildenv.2015.03.035

Wolverton BC (1997), How to grow fresh air: 50 houseplants that purify your home or office. Penguin Books, New York

Wood RA, Burchett MD, Alquezar R, et al (2006) The potted-plant microcosm substantially reduces indoor air VOC pollution: I. Office field-study. Water, Air, and Soil Pollution 175:163-180. https://doi.org/10.1007/s11270-006-9124-z

World Health Organization (2004) Guidelines for Drinking-Water Quality. ISBN: 9789241547611. https://www.who.int/water_sanitation_health/publications/gdwq3rev/en/. Accssed 6 December 2020.

World Health Organization (2010) WHO guidelines for indoor air quality: selected pollutants. https://www.who.int/airpollution/guidelines/en/. Accessed 17 September 2020

World Health Organization (2015) WHO Regional Office for Europe. Economic cost of the health impact of air pollution in Europe: Clean air, health and wealth. https://www.euro.who.int/en/media-centre/events/events/2015/04/ehp-mid-term- 
review/publications/economic-cost-of-the-health-impact-of-air-pollution-in-europe. Accessed 17 September 2020

World Health Organization (2018) Burden of Disease from Household Air Pollution for 2016. https://www.who.int/airpollution/data/HAP_BoD_results_May2018_final.pdf?ua=1. Accessed 17 September 2020

Yang DS, Pennisi SV, Son K-C, Kays SJ (2009) Screening indoor plants for volatile organic pollutant removal efficiency. HortScience 44:1377-1381. https://doi.org/10.21273/hortsci.44.5.1377

Yoneyama Y, Kim HY, Morikawa H, Srivatava HS (2002) Metabolism and detoxification of nitrogen dioxide and ammonia in plants. In: Omasa K, Saji H, Youssefian N, Kondo N (ed) Air pollution and plant biotechnology-Prospects for Phytomonitoring and Phytoremediation. Springer, Tokyo, 2002, pp 221-234

Zhou W, Wang J, Chen P, et al (2017) Bio-mitigation of carbon dioxide using microalgal systems: Advances and perspectives. Renewable and Sustainable Energy Reviews 76:1163-1175. https://doi.org/10.1016/j.rser.2017.03.065 


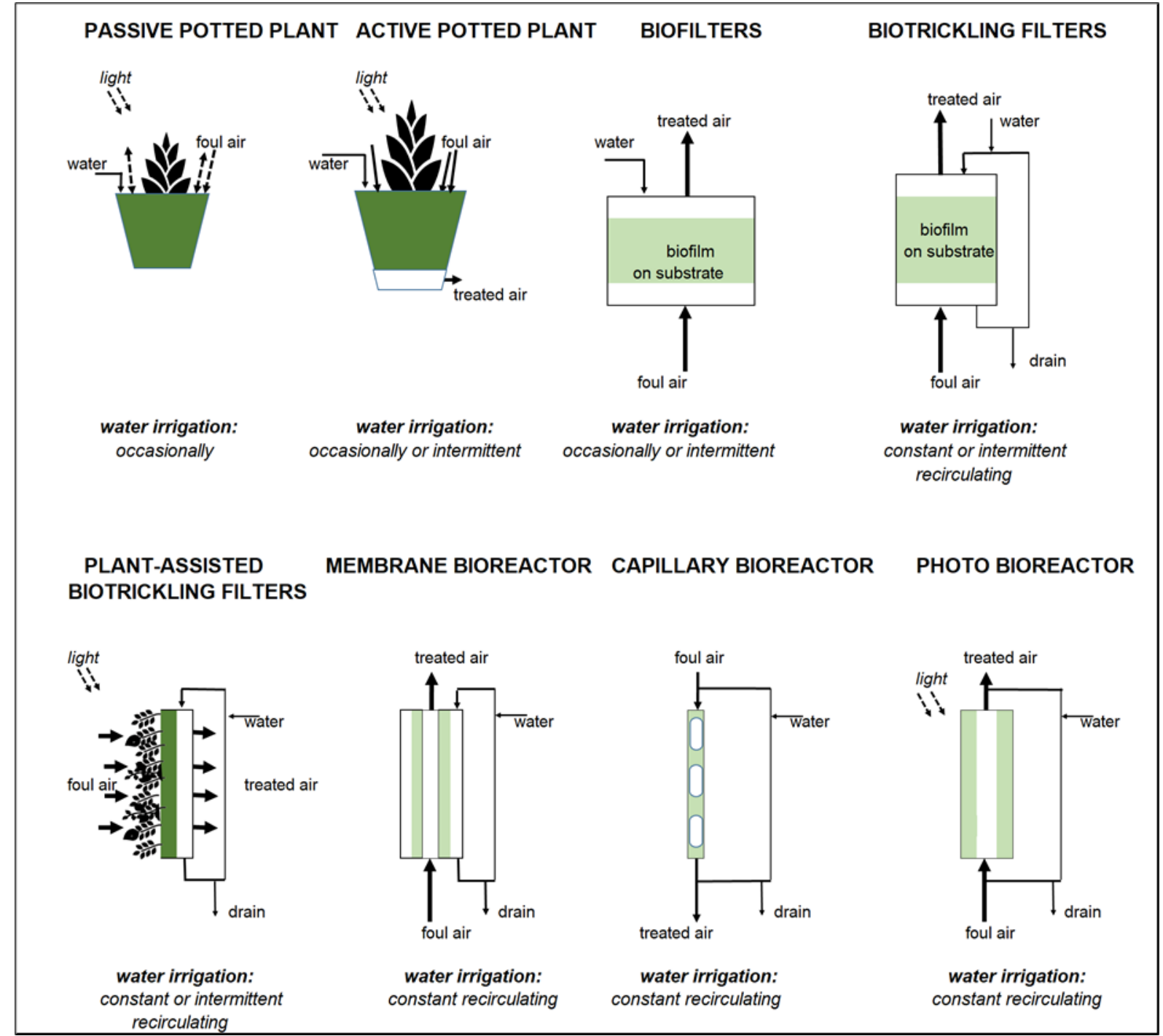

Figure 1: Process schematics of typical biological air treatment system design configurations. 


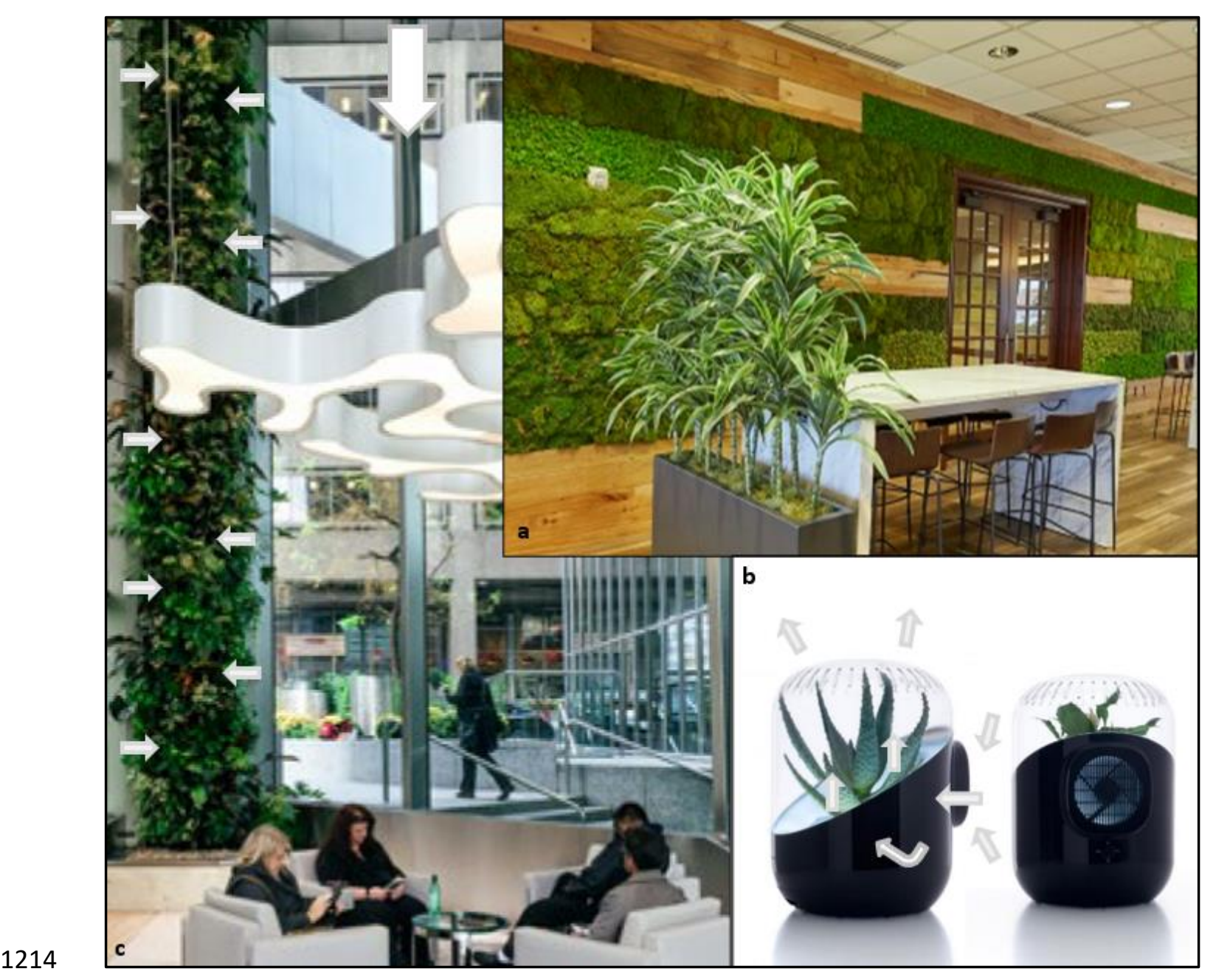

1215 Figure 2: Examples of commercially available plant-based systems for indoor environments:

1216 (a) an aesthetic passive moss wall (courtesy of Ambius), (b) an active potted plant (courtesy of

1217 Andrea) and (c) a vertical active green wall integrated with the building HVAC system 1218 (courtesy of Nedlaw Living Walls). 


\section{HYBRID: CAPILLARY ASSISTED GREEN WALL}

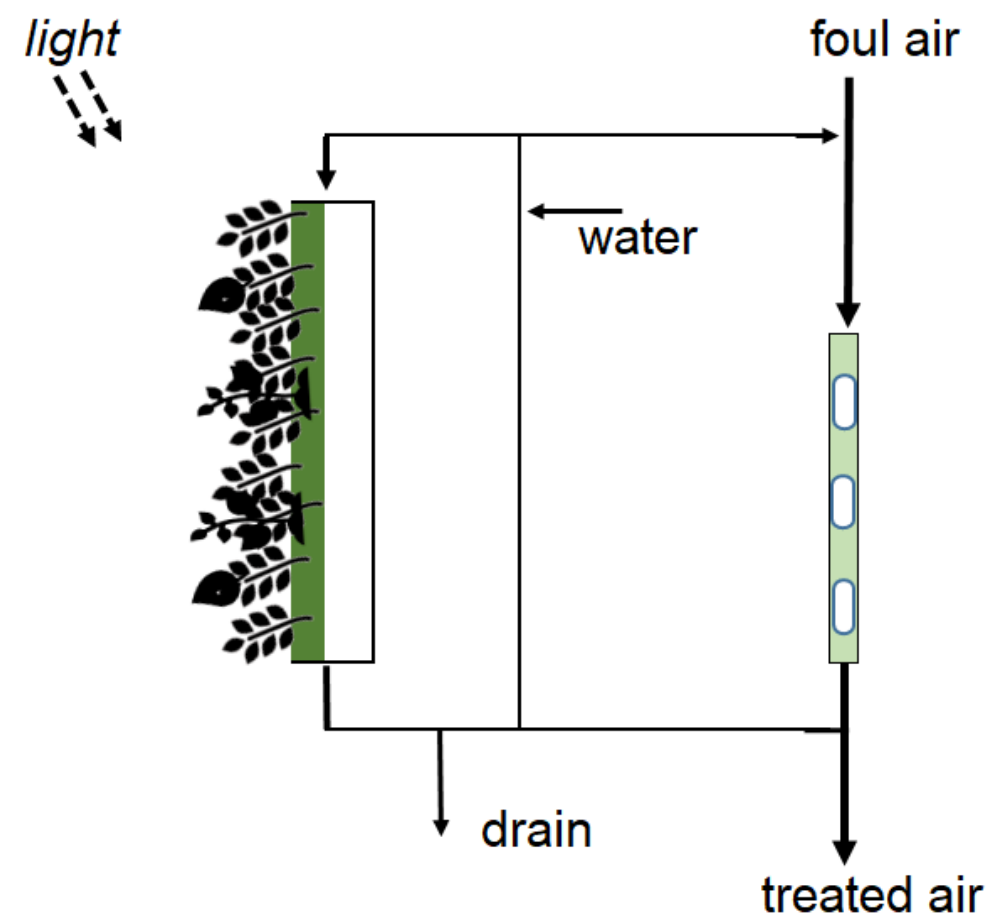

\section{water irrigation:}

constant or intermittent constant recirculating recirculating

1221 Figure 3: A schematic of a vertical active green wall combined with a capillary bioreactor to enhance mass transfer, improving the overall indoor air purification capacity. 


\section{HYBRID: \\ MEMBRANE ASSISTED GREEN WALL}

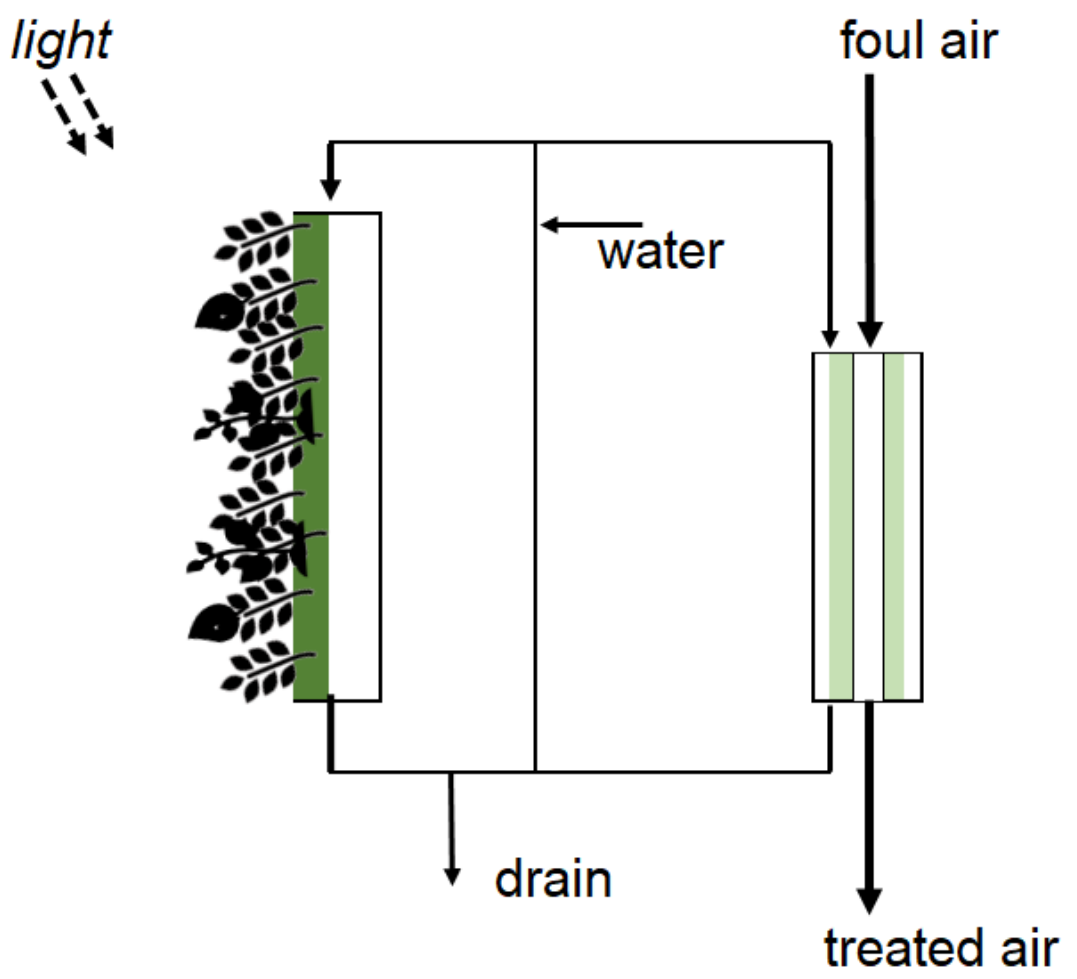

water irrigation:

constant or intermittent constant recirculating

recirculating

1225 Figure 4: A schematic of a vertical active green wall combined with a dense-phase membrane

1226 bioreactor to enhance air purification while eliminating the release of bioaerosols and moisture. 


\section{HYBRID: MICRO-ALGAE ASSISTED GREEN WALL}

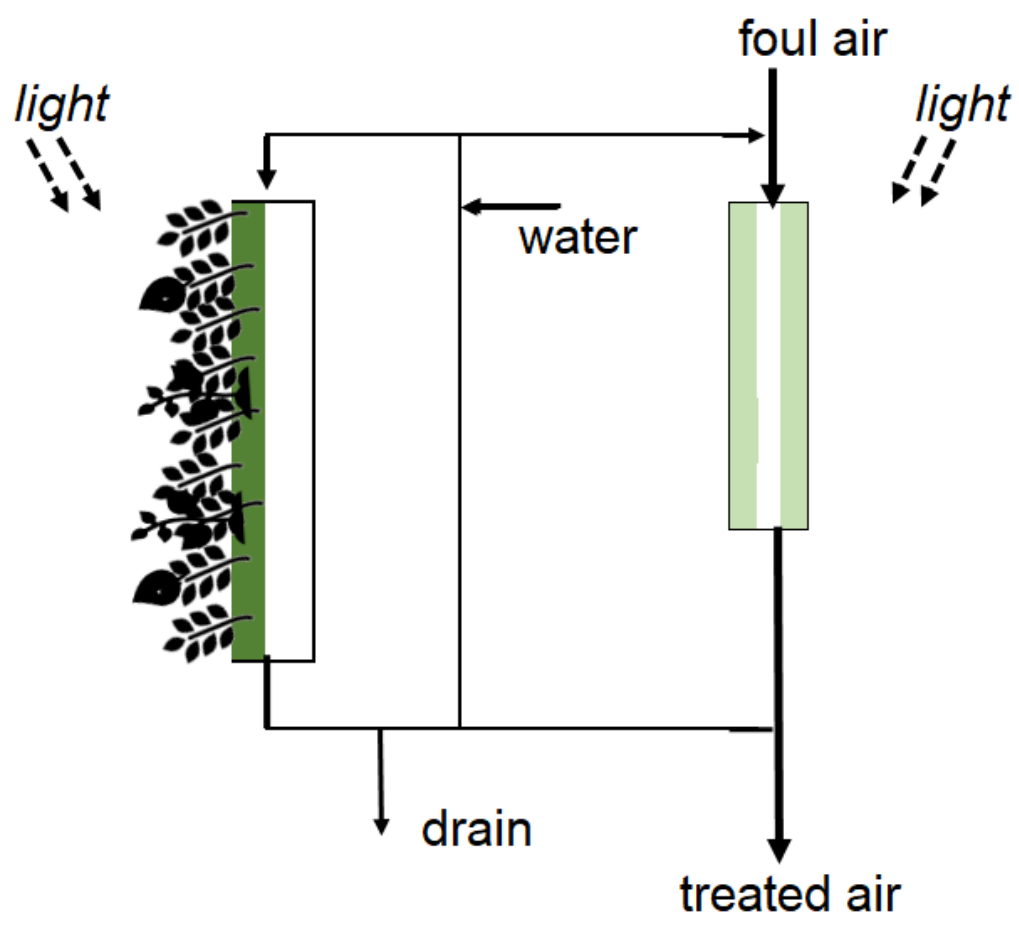

water irrigation:

constant or intermittent constant recirculating recirculating

Figure 5: A schematic of a photo-bioreactor containing microalgae combined with a vertical active green wall to enhance $\mathrm{CO}_{2}$ abatement of botanical-plant green walls. 